\title{
Article \\ The Horse and the Lion in Achaemenid Persia: Representations of a Duality
}

\author{
Eran Almagor
}

check for

updates

Citation: Almagor, Eran. 2021. The Horse and the Lion in Achaemenid Persia: Representations of a Duality. Arts 10: 41. https://doi.org/ 10.3390/arts10030041

Academic Editors: Branko F. van Oppen de Ruiter and Chiara Cavallo

Received: 4 June 2020

Accepted: 25 April 2021

Published: 23 June 2021

Publisher's Note: MDPI stays neutral with regard to jurisdictional claims in published maps and institutional affiliations.

Copyright: (C) 2021 by the author. Licensee MDPI, Basel, Switzerland. This article is an open access article distributed under the terms and conditions of the Creative Commons Attribution (CC BY) license (https:// creativecommons.org/licenses/by/ $4.0 /)$.
Independent Researcher, P.O. Box 3410, Jerusalem 91033, Israel; eranalmagor@gmail.com

\begin{abstract}
This paper explores the ambiguous Persian Achaemenid attitude towards the horse and the lion. It examines the way these animals appear in imperial official presentations, local artifacts throughout the empire and Greek textual representations. In the case of the stallion, it looks at the imagery of horse riding or the place of the horse in society and religion alongside the employment of steeds in chariots. Images of the lion are addressed in instances where it appears to be respected as having a significant protective power and as the prey of the chase. This paper attempts to show that this ambiguity corresponds roughly to the dual image of the Persians as both pre-imperial/nomad and imperial/sedentary (and hence allegedly luxurious), a schism that is manifest in both the self-presentation of the Achaemenids and in the Greek texts.
\end{abstract}

Keywords: horse; lion; Achaemenid; Ancient Persia; animals; Assyrian Empire; Medes; nomads; art history; archaeology

In a passage from Diodorus Siculus, the courtier Tiribazus, faced with charges of treason, tells his judges how once he had saved the Great King's life:

Once during a hunt, while the king was riding in a chariot, two lions came at him, tore to pieces two of four horses belonging to the chariot, and then charged upon the king himself; but at that very moment Tiribazus appeared, slew the lions, and rescued the king from the danger. ${ }^{1}$

The episode has several uncharacteristic features, like the mention of two lions attacking the king-instead of one, which was a familiar scene in Ancient Near Eastern iconography-and the depiction of the courageous killing of the beast not by the monarch but by a courtier-since this deed was normally the privilege of the king whenever he was on site. Compare the episode involving Alexander the Great and Lysimachus, echoing the incident of Artaxerxes I and Megabyzus (discussed below). ${ }^{2}$ Yet, this concise picture presents the two animals which were at the very core of the Persian imperial ideology, and which are the subject of the present paper, namely the horse and the lion. ${ }^{3}$

\section{The Horse}

The domestication of the horse (Equus caballus) occurred in the fourth millennium BCE in the Eurasian plains, and appeared in the Ancient Near East already in the second millennium BCE. ${ }^{4}$ In both nomadic and sedentary types of society, the domesticating of

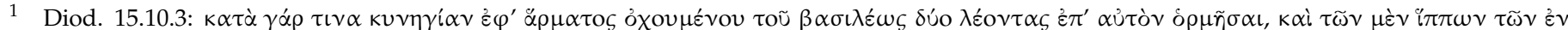

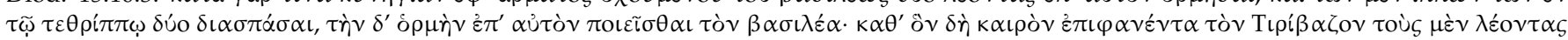

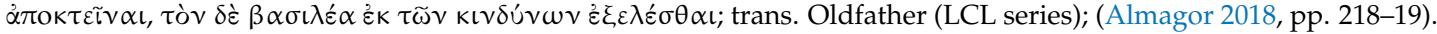

2 Curt. Ruf. 8.1.14-16; cf. Hdt. 3.32.1.

3 For reasons of space, the discussion is not intended to be comprehensive.

4 See (Littauer and Crouwel 1979, pp. 24-26; Kelekna 2009, pp. 93-94; Gheorghiu 1993). The theory that horse riding was as early as the fourth millennium has been contested and debated; for which, see (Zarins 1978, pp. 4-11; Anthony et al. 1991; Anthony and Brown 2000; Levine 1999; Drews 2004, pp. 12-26: "occasional riding"). The practice came from the outside into Iran, where the native equid was the Equus hemionus onager; for which, see (Littauer and Crouwel 1979, pp. 23-24; Kelekna 2009, pp. 24, 43; Potts 2014, p. 49). Note the manner in which the hybrid hemionos is used to symbolize Cyrus the Great in Herodotus (1.55, 1.91; cf. 3.151); see (Asheri et al. 2007, pp. 115, 157). 
the wild horse was important. ${ }^{5}$ Traditionally, horse riding was considered alien to the sedentary civilization, as a sentiment from the early second millennium BCE clearly reveals. ${ }^{6}$ Conversely, the horse was rather prized and appreciated in particular by nomadic societies (more below). Yet, in the Persian Empire, as envisaged by the Greeks, the horse came to have an indispensable role within a sedentary society; as claimed by Kelekna (2009, p. 2): "rapid horsepower greatly extended the scale and complexity of civilization". The most striking example in imperial Persia was the famous postal or messenger system, described by Herodotus, in the context of the way the news of the disaster in Salamis (480 BCE) spread to the Persian heartland:

There is nothing mortal that accomplishes a course more swiftly than do these messengers, by the Persians' skilful contrivance. It is said that as many days as there are in the whole journey, so many are the men and horses that stand along the road, each horse and man at the interval of a day's journey. These are stopped neither by snow nor rain nor heat nor darkness from accomplishing their appointed course with all speed. The first rider delivers his charge to the second, the second to the third, and thence it passes on from hand to hand, even as in the Greek torch-bearers' race in honour of Hephaestus. This riding-course is called angarēion by the Persians. ${ }^{7}$

The last term, $\dot{\alpha} \gamma \gamma \alpha \rho \dot{\eta} \operatorname{lo\zeta }$, is connected to the word $\alpha \gamma \gamma \alpha \rho \circ \varsigma$, which perhaps signified "herald". ${ }^{8}$ It is an allusion to Aeschylus' representation of the announcement of the fall of Troy by Clytaemnestra (Agamemnon 282-83), where a series of fire signals conveying the calamity is depicted as "courier fire" ( $\alpha \gamma \gamma \alpha \rho o v \pi \tilde{u} \rho)$. Although Herodotus insinuates a comparison between the two eastern empires and plays upon the association of Persia and Troy, ${ }^{9}$ there is also a marked difference between the two. The Persians, unlike the Trojans, endure their disaster. Furthermore, while it is a (wooden) horse, which led to the Trojan tragedy, ${ }^{10}$ nothing symbolizes the Persian strength and perseverance like the postal system that employs horses. Indeed, to underscore this fact Herodotus hints at the contrast between the substance of the message (defeat at sea) and the method of its diffusion (mastery of the land). ${ }^{11}$

In his Cyropaedia, Xenophon attributes the same postal service to Cyrus the Great and emphasizes again the role of horses, their presence in stations and the fact that the intervals between stations were one day's ride:

He [Cyrus] experimented to find out how great a distance a horse could cover in a day when ridden hard but so as not to break down, and then he erected post-stations at just such distances and equipped them with horses and men to take care of them; at each one of the stations he had the proper official appointed to receive the letters that were delivered and to forward them on, to take in the exhausted horses and riders and send on fresh ones. They say, moreover, that sometimes this express does not stop all night, but the night-messengers succeed

5 "Nomadism" designates the life of seasonal migratory herders, periodically moving between grazing territories and pasture lands; for which, Arist. Polit. 1.1256a; Hippocr. De aer. 18; see (Potts 2014, pp. 2-3; Almagor 2014, p. 4).

6 A text from Mari: see (Durand 1998, pp. 2.484-2.488, text 732; Drews 2004, p. 42).

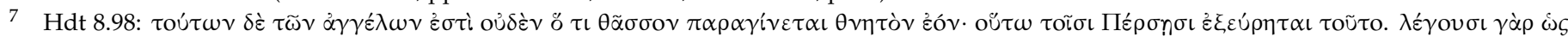

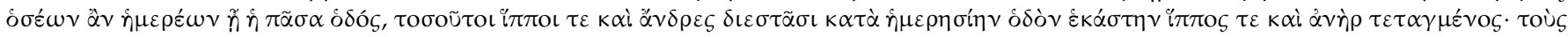

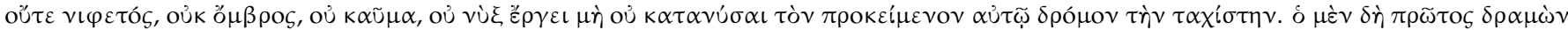

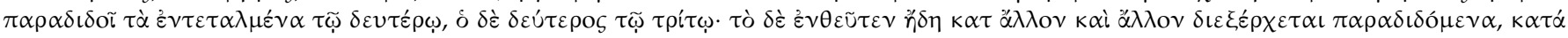

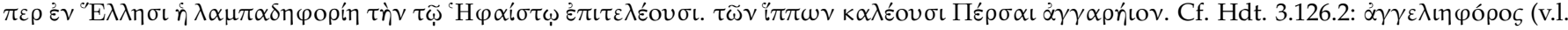
$\alpha \gamma \gamma \alpha \rho \dot{\imath} \operatorname{los}) ;$ trans. Godley (LCL series).

8 See Hesych. s.v. A 374b, Suda s.v. $\alpha$ 164-65. The origin of the word is most probably the Akkadian word agru(m) (LU.HUN.GA; LU.A.GAR, pl. Old Babylonian $a g r \bar{u}$, New Babylonian agrütu), "a hired man, hireling", in relation with igru(m), "hire, rent, wage", later specifically understood as a messenger and by derivation, the Aramaic iggartā (Almagor 2018, p. 153).

9 Cf. Hdt. 7.43: Xerxes sacrifices to Athena of Ilium in the "citadel of Priam" (Hall 1989, pp. 21-25).

10 See (Sparkes 1971).

11 See (Almagor 2021). 
the day-messengers in relays [ ... ] it is at all events undeniable that this is the fastest overland travelling on earth. ${ }^{12}$

The efficiency of the postal service was based upon the Royal Road system, which went back to the Neo-Assyrian imperial network, with its stations at fixed intervals, where horses and chariots could be changed. ${ }^{13}$ The horse thus contributed to the uniformity and the unification of the empire. ${ }^{14}$ It is no wonder that this animal was seen by the Greeks as a powerful symbol for Persian civilization. The disposition to view the steed in this manner was probably assisted by the fact that the taming of a horse entailed the breaking of its passion, impulsiveness, and unrestrained primeval uninhibited energies, and therefore was seen by the Greeks as a metaphor for the cultivating and nurturing progress itself. ${ }^{15}$

Another important vehicle in maintaining the Empire was the Persian cavalry; yet, surprisingly, there are only a few sporadic and scanty mentions of it in Greek texts in relation to actual clashes. ${ }^{16}$ The notable large-scale battles in which horsemen appear and which are depicted in Greek texts include those of Thymbrara $(547 / 6 \mathrm{BCE}){ }^{17}$ Malene (494 ВCE) ${ }^{18}$ Plataea (479 вCE) ${ }^{19}$ Cunaxa $(401 \mathrm{BCE}),{ }^{20}$ Granicus (334 вCE) ${ }^{21}$ Issus (333 вСЕ) ${ }^{22}$ and Gaugamela (331 BCE). ${ }^{23}$ A prominent absence of cavalry can be noted in Herodotus' account of the Battle of Marathon (490 BCE). ${ }^{24}$ This most definitely does not tell us much about the nature and role of the cavalry in the Persian army, but rather demonstrates Greek authors' and historians' inadequacy, their misapprehension of the situation and their lack of awareness of their own lack of knowledge; occasionally, it may even say something about the unsuitability of conditions for the employment of Persian horses. ${ }^{25}$

Herodotus (1.125) provides a rather rigid distinction between nomadic Persian tribes

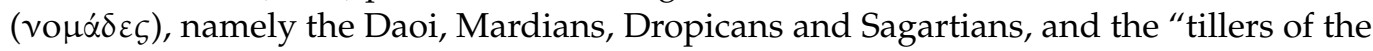
land" ( $\dot{\alpha} \rho \tau \tau \tilde{\eta} \rho \varepsilon \zeta)$, the Panthaliaeans, the Derusiaeans and the Germanians-in addition to the three leading tribes, the Pasargadae (from whom came the Achaemenids), the Maraphians and the Maspians. It is clear that Herodotus points at the co-existence of the two modes of life within Persian reality or at least self-image. ${ }^{26}$ The nomadic pre-imperial mode of life of the Persians, as that of the other Iranians, was dependent on the spread of their employment of the horse. ${ }^{27}$ Some of the groups Herodotus mentions as "Persian"

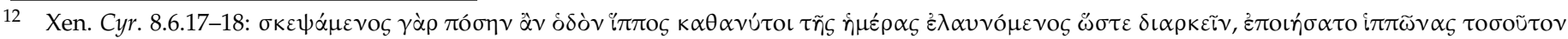

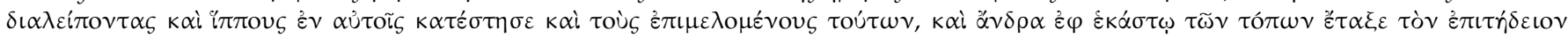

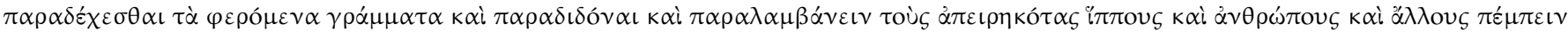

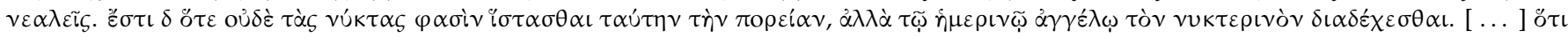

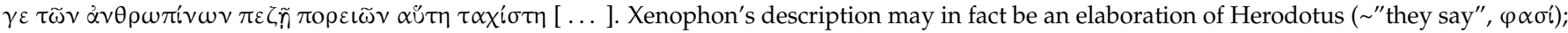
trans. Miller (LCL series). See (Almagor 2021).

13 See (Graf 1994, pp. 181-84; Kinnier-Wilson 1972, pp. 57-60).

14 See (Kelekna 2009, p. 3).

15 Cf. Plat. Apol. 20a, 25b, Rep. 3.413d, Leg. 2.666e; cf. Gorg. 516ab; Xen. Mem. 4.1.3.

6 On the Achaemenid cavalry, see (Tuplin 2010).

Xen. Cyr. 6.2.16, 7.1.3, 8, 19, 26, 28, 31, 37, 39-40, 46, also 6.2.18, 7.1.22, 27, 48-49; cf. Hdt. 1.80; Polyaen. 7.6.6.

Hdt. 6.29 .

Hdt. 9.20, 22-23, 32 and 71.

Xen. Anab. 1.7.11, 1.8.5-1.8.6, 9, 21, 24-25, 1.9.31.

Diod. 17.19-21; Arr. Anab. 1.14.4, 1.15.2 and 4.

Diod. 17.33.6, 34.3; Arr. Anab. 2.8.5, 10, 9.1, 11.2-11.3 and 7-8.

23 Diod. 17.58.2-4, 59.2-8, 60.4-6, 61.3; Arr. Anab. 3.11.3-8, 3.14.1-15.2. Other sporadic mentions of Persian cavalry units include Hdt. 8.113; Xen. Anab. 3.4.35, 4.3.3, 12, 17, 22-23, 6.5.7, Hell. 3.2.15, 3.4.13-14, 22-24, 4.1.17, 4.8.19, Cyr. 6.2.4, 7; Polyaen. 7.14.2-3, 7.21.6-7, 7.28.2, also 5.16.2.

24 Hdt. 6.112-13.

25 See (Drews 2004, pp. 82, 113, 116-18; Tuplin 2010, pp. 176-77, 179, 181).

26 See (Potts 2014, p. 89).

27 See (Frye 1984, p. 40): "[ . . . ] the movement of peoples beginning about 1000 BC was the result, in large measure, of a great expansion in the use of the horse [ . . ]". See (Linder 1981; Potts 2014, p. 119): "It seems certain that the horse made some of the groups [ ... ] more mobile, though the evidence pertaining to non-military matters remains sparse". According to one view, nomadic pastoralism was predominant in prehistoric and Bronze Age southwestern and south-central Iran (Alizadeh 2008). Yet, cf. the reasonable rejection of this opinion by (Potts 2014, pp. 8-46). 
appear in military engagements, hence pointing at the place of nomadic horsemanship in the service of the sedentary Empire, as Persian cavalry. ${ }^{28}$

The sacred Zoroastrian texts of the Avesta, due to the fact that they were composed and transmitted during a long period-its older layer containing ancient information (dated as far back as the tenth century BCE) although written much later (fourth to tenth centuries (E) - bear witness to a certain change of values, most probably between the sedentary mode of life, in which horses were employed in wagons and chariots, and a nomadic existence, in which horsemanship was prominent. One of the classes of the older

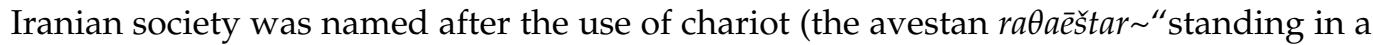
chariot", i.e., chariot fighters, Yasna 19.17). ${ }^{29}$ Yet, in another part of the Avesta (Vendidad 14.9), one of the arms suited to this class is a horse saddle, implying actual riding. ${ }^{30}$ Gods were given chariots and horses, ${ }^{31}$ but elsewhere heroes (Yasna 11.2, Yasht 5.53, 112, 117, 10.11) and divinities (Yasht 10.102) are presented riding on horses. Gods also appear as horses as their incarnation (Yasht 2.13, 8.9, 18, 20, 26, 30, 46, 14.9). There are references to horse riding in the Avesta ${ }^{32}$ as well as numerous names derived from the stem Aspa$(=$ horse $){ }^{33}$

Remnants of the value system, which attached great importance to horses, can be seen in the Achaemenid royal inscriptions. As in the Avesta, where other gods are portrayed giving swift horses to men, ${ }^{34}$ there also appears in Darius' description of the land of Persia (Fars/Parsa) a reference to steeds as a gift from Ahura Mazda ("Lord Wisdom", the supreme Zoroastrian good deity): "This country [ ... ] that Ahura Mazda bestowed upon me, good, possessed of good horses (uvaspâ), possessed of good men". ${ }^{35}$ In this context, it is worth mentioning the importance of the Choaspes River, which literally means "possessing good horses" (OIr. *hu-aspa-, see Late Avestan huuaspa- or Huuaspā-: Yasht 19.67); the river rises in southern Media, flows by Susa, and is famous for the fact that its contents are the only water drunk by the king. ${ }^{36}$ One should also note the portrayal of Ahura Mazda's benefits by Darius: "A great god is Ahura Mazda, who makes excellence in this earth, who makes man in this earth, who makes happiness for man, who makes good horses and good chariots (uvaspâ urathâcâ)". ${ }^{37}$

Aeschylus (Pers. 26) identifies the Persians with horseback riding (and with archery).$^{38}$ It is certainly difficult to uphold the picture of several Greek depictions, such as those of Xenophon (Cyr. 1.3.3) or Strabo (11.13.5), according to which the art of horse riding among the Persians was attained very late only through Median mediation..$^{39}$ After all, in the reconstruction of the Neo Elamite cylinder seal of "Kurash of Anshan" 40 (i.e., Cyrus I, the grandfather of Cyrus the

28 Daoi: Arr. Anab. 3.11.37, Curt. Ruf. 4.12.5; Mardians: Arr. Anab. 3.11.5, 3.13.1; Dropicans (i.e., Derbicans): Curt. Ruf. 3.2.7; Sagartians: Hdt. 7.85. The evidence is assembled in (Potts 2014, pp. 88-119).

29 Cf. Yasht 13.88-89. Cf. Yasna 50.6 (raiti-, "charioteer" [i.e., of my tongue]). See (Benveniste 1932, p. 133; Kellens 1974, pp. 231-32).

30 See (Gershevitch 1959, pp. 69-70).

31 See Yasna 2.5, 6.4, 57.27-8, 62.8, 65.12, 70.6; Yasht 2.9, 5.11, 13, 79, 8.38, 10.52, 66, 76, 125, 136, 17.1, 4, 12, 21, 23, $19.51-2$.

32 See Yasna 11.2, 40.3, 65.4; Yasht, 5.4, 11, 101, 10.3, 11, 20, 47, 13.7, 15.12, 19.76.

3 See (Justi 1895, p. 486; Mayrhofer 1977, p. 22). The OPers. variant is Asa-.

34 See Yasna 8.19, 44.18, 50.7 (Ahura Mazda); Yasht 5.86, 98, 130, 9.7, 12, 16, 20, 24, 28, 10.3, 17.12, 18.5, 19.67. See (Tuplin 2010, p. 129, n. 115).

35 DPd, 8 (trans. Kent); cf. DSf.11; DSp.3, DZc.4: "possessed of good charioteers, of good horses". It is followed in the unauthentic AmH, 6-9 (Ariaramnes' inscription from Ecbatana/Hamadan): "This country Persia which I hold, which is possessed of good horses, of good men".

36 Hdt. 1.188.1-2, 5.49.7, 5.52.6; Ctesias, FGrH 688 F 37; Tibullus, 3.7.140; Strabo 1.3.1, 15.3.4; Curt. Ruf. 5.2.9; Paus. 10.31.7; Nicander, Theriaca 890; Ath.

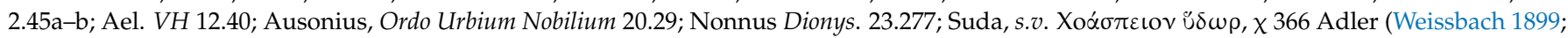
Tuplin 2010, p. 128). Plut. Art. 12.6 with (Almagor 2018, pp. 117-18).

37 DSs, 5 (trans. Kent). The name of Darius' own father is composed of a horse stem: Hystaspes (OPers. Vištāspa): DB 1.2-4, 2.93-4, 97, DNa.12-13, DSa.2, Hdt. 1.183, 209-11, an Avestan name: Yasna 12.7, 23.2, 26.4, 28.7, 46.14, 51.16, 53.2.

38 See (Drews 2004, p. 116).

39 See (Briant 2002, pp. 14, 19-20). Xen. Cyr. 4.3.4-23, esp. 10-20 on the introduction of horse riding among the Persians as part of the new establishment of the cavalry by Cyrus the Great. Cf. Cyr. 8.6.10.

40 Anshan, the name of western Elamite region, was at one point separated from Elam and identified later within the Fars/Parsa (Persia) province, homeland of the Achaemenids. See (Hansman 1972, pp. 107, 108 + n. 60; Potts 2005). 
Great, c. 600 BCE), a mounted spearman appears to leap over two bodies of soldiers (Figure 1),

41 clearly indicating that this knowledge was already in the possession of the Persians. ${ }^{42}$

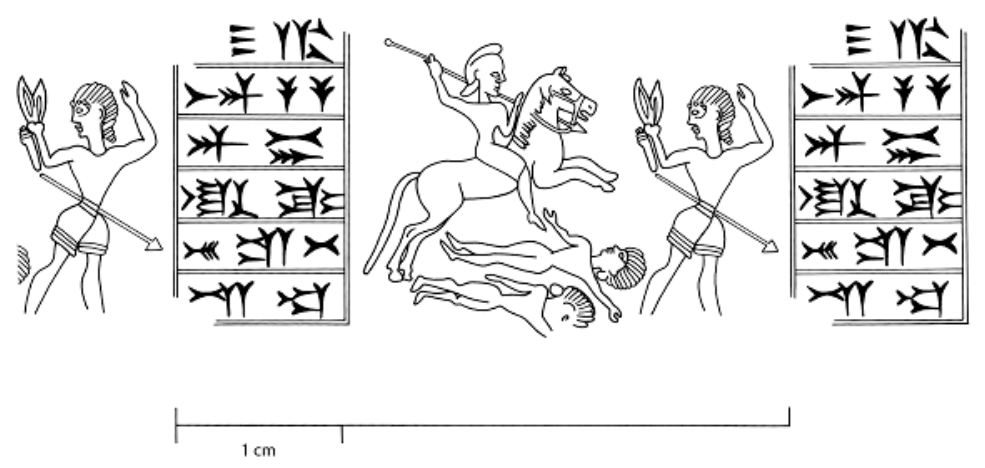

Figure 1. Collated line drawing of the heirloom seal of Kurash the Anzanite (PFS *93) [image courtesy of the Persepolis Fortification Archive Project and the Persepolis Seal Project].

Medes (OPers. Māda), the tribes settling in western Iran from the second century BCE, and who rose to prominence in the area in the middle of the seventh century BCE, were, however, of the earliest able riders in the Iranian plateau. ${ }^{43}$ In Tepe Siyalk (VI, Necropolis B), in central western Iran, bronze cheekpieces and bits together with a cylinder seal, dated to the ninth or eighth centuries BCE and showing two mounted archers, were discovered by Roman Ghirshman. ${ }^{44}$ Nearby, the plain of Nisaea (OIr. *Nisāya-, "settlement", MPers. Nisāy, NPers. Nesā), was the origin place of the famous Nisaean horses (now extinct), known for their speed and size. ${ }^{45}$ Indeed, Greek historiographic convention since the classical period onward, ${ }^{46}$ as well as the official Persian imagery, have emphasized the fact that the Medes were verily associated with horse riding. This can be seen in the Persepolis frieze, in which they are depicted as wearing the so-called riding costume (below). ${ }^{47}$ It is important to stress that this was an imperial image, in which the Persians followed their ninth- and eighth-century BCE Assyrian predecessors, who essentially associated horses with the Medes. ${ }^{48}$

In both the artistic and textual representations of the horse among the Persians, the animal serves three important roles in terms of ability, honor and religious function. In imperial Achaemenid ideology, knowledge of horsemanship was considered a requirement for the legitimization of the claim to the throne, since it displayed both might and military valor. This is evident in Darius' self-presentation in the Naqsh-i-Rustam inscription, on the façade of his tomb:

As a horseman I am a good horseman (asabâra uvâsabâra amiy). As a bowman, I am a good bowman both afoot and on horseback (asabâra). As a spearman I am a good spearman both afoot and on horseback (asabâra). ${ }^{49}$

It is this representation that is reflected in Xenophon' picture of the royal qualities of Cyrus the Younger in the Anabasis:

41 PFS *93; See (Garrison and Root 1996, pp. 6-7, figure 2a; Garrison 2011). The cylinder seal is preserved in impressions on a series of clay tablets from the Persepolis Fortification archive.

42 Cf. the descriptions of a land in Fars/Persia as suitable for horses: Arr. Ind. 40.3, cf. Diod. 19.21.2-3; Strab. 15.3.1.

43 See (Kelekna 2009, pp. 63-4, 105, 119; Drews 2004, pp. 69, 107-8, 114).

44 See (Ghirshman 1954, p. 80, fig. 31; Drews 2004, pp. 67, 69, 78-79).

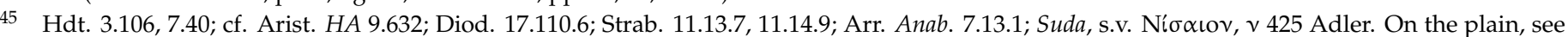
(Hanslik 1936, p. 712; Ghirshman 1954, p. 94; Herzfeld 1968, pp. 15-16; Gabrielli 2006, pp. 26-27).

46 Polyb. 10.27.1: "Media is the most notable principality in Asia, both in the extent of its territory and the number and excellence of the men and also of the horses it produces" (trans. Paton, LCL series), also 5.44.1.

47 See, however (Potts 2014, pp. 72-73).

48 See (Radner 2003).

49 DNb, 41-44 (Kent trans.); for this association between kingdom and a horse, also see Xen. Cyr. 8.3.35-50. 
[Cyrus was] the most devoted to horses $(\varphi \imath \lambda \iota \pi \pi$ ó $\tau \alpha \tau o \zeta)$ and the most skilful in managing horses [... ] when he was of suitable age, he was the fondest of hunting and, more than that, the fondest of incurring danger in his pursuit of wild animals. ${ }^{50}$

Herodotus also appears to reflect this Achaemenid ideological link between horsemanship and royalty through the figure of Darius I, albeit in two tongue-in-cheek portrayals. The first is the ironic manner in which this association is depicted: it is through a ruse involving a horse's neighing at dawn that Darius obtained the crown (3.84-88) rather than through his ability to ride a horse. ${ }^{51}$ The second is the injury inflicted by Darius' hasty leap off his horse while engaging in a hunt of wild beasts (3.129): he twisted his foot quite aggressively. ${ }^{52}$ This description again hints at Darius' flawed horsemanship, and by inference, insinuates the problematic legitimacy of his claim to the throne. In all these examples, we can observe the social importance of horse riding in a nomadic community, with the focus being on the personal abilities of a person to break or control the horse. The story of Darius' rise to power among the seven conspirators particularly assumes certain equality among members of the aristocratic elite, and the award given to merit and ability.

This importance of horsemanship to the Persians is sustained by Greek authors in the place they allot to it within Persian education. The locus classicus is Herodotus (1.136), who describes the Persians as educating the children three things only: riding, the use of bows and speaking the truth. ${ }^{53}$ Xenophon in his Cyropaedia portrays the young Cyrus as surpassing his peers in horsemanship:

when he saw a deer spring out from under cover, he forgot everything that he had heard and gave chase ... somehow his horse in taking a leap fell upon its knees and almost threw him over its head. However, Cyrus managed, with some difficulty, to keep his seat, and his horse got up. ${ }^{54}$

Even more specific is a passage in the dialogue Alcibiades 1 (121e-122a), a work attributed in antiquity to Plato, though its authenticity is rightly doubted. ${ }^{55}$ This passage, which outlines the customary tutoring of the young among the Persians, incorporates horsemanship and hunting (for boys from the age of seven to fourteen). An instance of the Persian confidence in their horsemanship is given by Xenophon (Hell. 3.4.12), who relates that Tissaphernes is convinced he will be victorious against Agesilaus' infantry because of his own cavalry. Previously, Herodotus (5.111-12) recounts that Artybius the Persian trained his horse to rear up against hoplites.

This emphasis on horsemanship reflects the nomadic value system of the pre-imperial Persians. Together with the transformation of the Persians themselves, their horses also changed through training and coaching. A telling example is revealed by conjoining two distinct anecdotes. In the clash of Cyrus the Great and Croesus, Polyaenus (7.8.1) tells us, the horses in the army of the former were shaken by the gleam of weapons of Croesus'

50 Xen. Anab. 1.9.5-6, trans. Brownson (LCL series); also Anab. 1.2.7: Cyrus partook in hunting "whenever he wished to give himself and his horses exercise". Cf. 1.8.3, 15. The motif is found also in Cyrus' letter to the Spartans (Plut. Art. 6.4), sent to solicit their assistance in his bid for the throne against his brother Artaxerxes II; among the monarchic traits which Cyrus finds lacking in his brother is the ability to keep a place on his horse

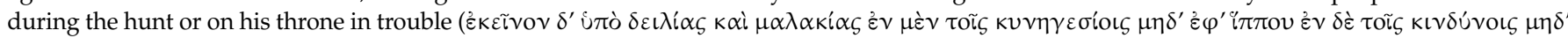

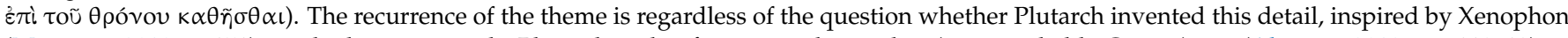
(Mossman 2010, p. 151) or whether, conversely, Plutarch took it from an earlier author (most probably Ctesias); see (Almagor 2018, pp. 110-12).

51 Cf. Ctesias FGrH 688 F 13.17. The later author Ptolemaeus Hephaistion (Photios, Bibl. cod. 190, 148b Bekker) produced another horse-related story concerning Darius, namely, that he was exposed by his mother and was fed on mares-milk by a horse guardian, Spargapises; for the latter name, see Hdt. 1.211.

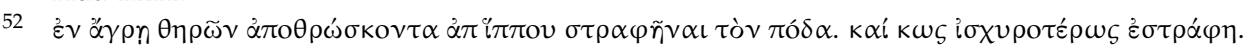

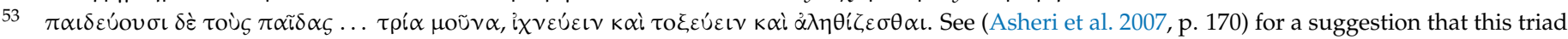
may arise from a miscomprehension of royal formulae of glorification (as horsemen and archers). Cf. Strabo (15.3.18) who adds (from Polycleitus of Larissa?) the use of spears as a component in the Persian education.

54 Xen. Cyr. 1.4.8, trans. Miller (LCL series); for his age, see 1.4.5.

55 Diog. Laert. 3.37; cf. Apul. Apol. 25; Amm. Marc. 23.6.32; see (Schleiermacher 1836, pp. 328-36; Shorey 1933, p. 415; Smith 2004). Cf. the surveys in (Denyer 2001, pp. 14-26; Gribble 1999, pp. 260-61; Archie 2015, pp. 36-44). 
army ${ }^{56}$ and were frightened by the Lydian noise of the spears clanging upon their shields. Yet, According to Aelian, the Persians familiarized their horses to clamors and the bang of bronze "so that in war they may never be afraid of [ . . ] the clash of swords on shields". 57

The original mindset of the Persians was later combined with an imperial, sedentary worldview. A noticeable change is the growing importance of the chariot as a symbol of the central power and the growing remoteness of the king from the horse, with the ensuing lessening stress on the abilities of the king as a rider. This is in fact at once both a return to the earliest stage of the employment of the horse, ${ }^{58}$ and a transition to a seemingly more refined state of the imperial Persians. This portrayal goes along with the Greek depictions of the decadent king as never touching the ground with his feet, ${ }^{59}$ occasionally confusing the (war) chariot $(\check{\alpha} \rho \mu \alpha)$ with the carriage ( $\alpha \rho \mu \alpha \dot{\alpha} \mu \alpha \xi \alpha$, covered four wheeled vehicle), a token of luxury. ${ }^{60}$

Greek written evidence sometimes counters this decadent picture by an archaic image of the Great King hunting mounted on a horseback. ${ }^{61}$ Certain descriptions, however, like the one at the beginning of this paper, which places the king in a chariot, are probably more accurate. They are also found in official imperial depictions of the Neo-Assyrian reliefs; of particular note are the wall panels of Ashurnasirpal II (r. 884-859 BCE), where the king is in a chariot, turning his head backward to face a lion charging from behind (Figure 2), ${ }^{62}$ or of Ashurbanipal (r. 668-631 BCE) hunting lions from his chariot (Figures 3 and 4). ${ }^{63}$ The horse chariot also appears in the Achaemenid seals like the one that will be further addressed below (Figure 5). ${ }^{64}$ Not only do these images echo armed clashes, but they also distance the monarch and set him as the great ruler, a measure taken among several others in order to underscore his exalted status.

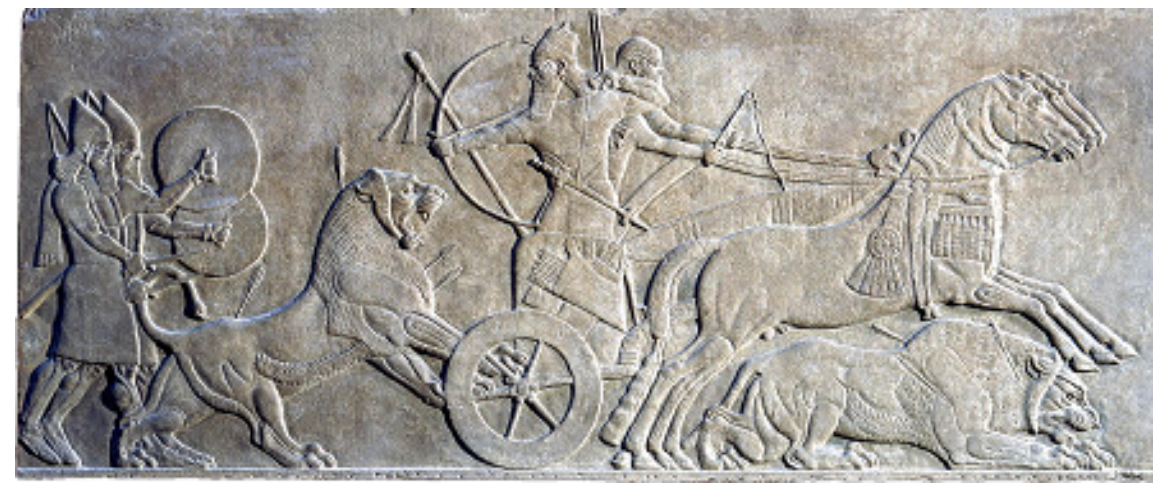

Figure 2. King Ashurnasirpal II hunting lions (BM inv. no. 124534; reg. no. 1847,0623.11); relief scene, gypsum; NW Palace, Nimrud (mod. Iraq); Neo-Assyrian, ca. 865-860 BCE [image courtesy of the Trustees of the British Museum, London].

56 Hdt. 1.27, 79-80 claims that the Lydian cavalry was excellent (Tuplin 2010, p. 172).

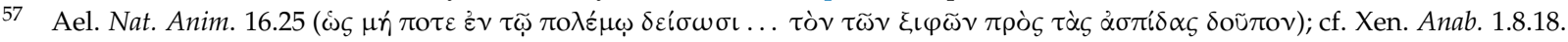

58 The horses were first used (before the second millennium BCE) for drawing chariots of war or wagons and for transport as paired draught animals. See (Littauer and Crouwel 1979, pp. 13, 22-23, 28-31, 33, 41-43, 56-59, 65-68, 82-86; Drews 2004, pp. 4, 23-25, 38, 40-48, 53, 55; Kelekna 2009, pp. 45-52, 73-76, 95-99). Evidence for riding, both figured and textual, substantially increases from the ninth century BCE, especially in Assyria (Littauer and Crouwel 1979, pp. 134-39). See (Frye 1984, p. 39): "true nomads could hardly exist without the use of horses primarily for riding, and this suggests that nomadism is a relatively late and sophisticated development of a pastoralism based on the use of wagons to follow the herds" (Downs 1961).

59 Cf. Deinon ap. Ath. 12.514a-b: "Whenever the king dismounts from his chariot, he does not leap down, nor is he supported by hands, but a golden stool is always put down for him, and treading on it he descends". Cf. Heracleides ap. Ath. 12.514c: "when [the king] came to the end of the courtyard, he mounted a chariot, but sometimes a horse; he was never seen outside the palace on foot".

60 See especially Hdt. 7.41, cf. 7.83. Cf. Aristoph. Acharn. 69-70; Xen. Hell. 3.1.13, Cyr. 3.1.40, 6.4.11; cf. Aesch. Pers. 1000-1; see also (Hall 1989, pp. 95-96).

61 See Xen. Cyr. 7.1.3, 7.3.6, 7.1.38, cf. Arr. Anab. 4.13.1. See (Gabrielli 2006, pp. 14-15).

62 BM inv. no. 124534 (Grayson 1991, no. 0.101.23.29).

63 BM inv. nos. 124850-51 and 54 (reg. no. 1856,0909.15); cf. BM inv. no. 124858 (Room C, Panel 5; preparation of chariot); see (Barnett 1976, p. 38, pl. 11; Weissert 1997, p. 340) (who even shows the existence of a topos of "Lion Hunt by Chariot (in the Plain)").

64 BM inv. no. 89132 (reg. no. 1835,0630.1); see (Frankfort 1939, p. 221, pl. 37d; Curtis and Tallis 2005, no. 398). 


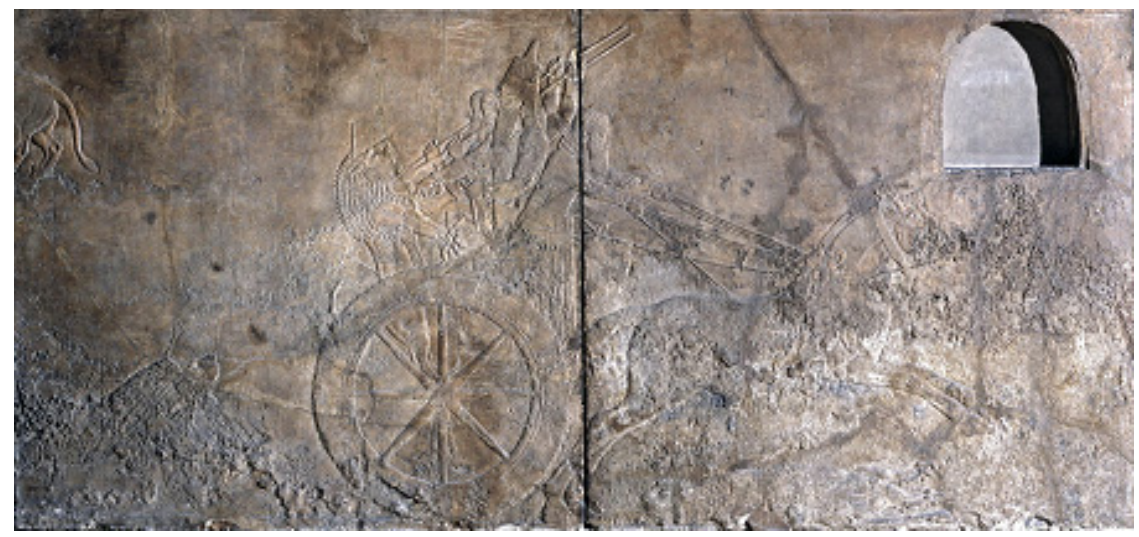

Figure 3. King Ashurbanipal hunting lions (BM inv. nos. 124850-51; reg. no. 1856,0909.15); relief scene (panels 20-21), gypsum; N Palace (Room C), Nineveh (mod. Iraq); Neo-Assyrian, ca. 645-635 BCE [image courtesy of the Trustees of the British Museum, London].

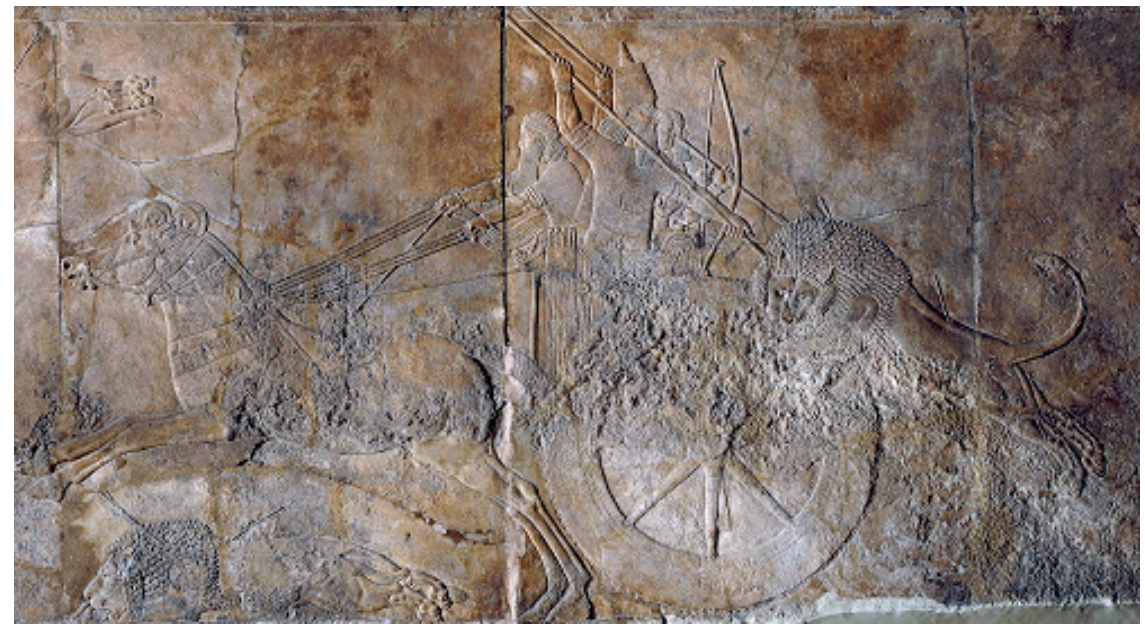

Figure 4. King Ashurbanipal striking lion (BM inv. no. 124854) (as preceding).
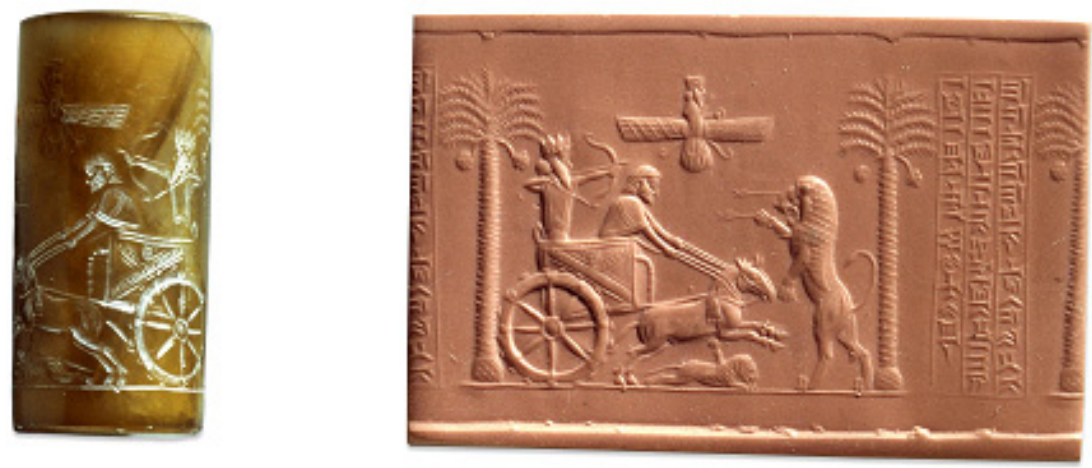

Figure 5. The Great King Darius hunting lions (BM inv. no. 89132; reg. no. 1835,0630.1); cylinder seal, chalcedony (with modern impression); found in Thebes (?), Egypt; Achaemenid, ca. 6th-5th cent. BCE [image courtesy of the Trustees of the British Museum, London]. 
The absence of any depiction of the Persian king as actually riding a horse may have to do with the fact that there is no representation of a mounted warrior in the Achaemenid monumental iconography. ${ }^{65}$ This is true, although in Greek imagination such equestrian

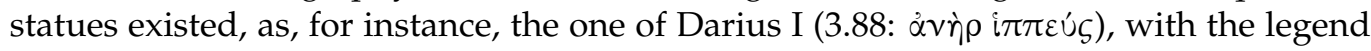
"Darius son of Hystaspes by the excellence of his horse". An interesting case is an undated letter (in Aramaic) of Arshama (Arsames), the satrap of Egypt probably from 458/7 or 454 until $407 \mathrm{BCE}$, at least. ${ }^{66}$ In that letter (A6.12 = Driver 9), Arshama apparently authorises rations from his men for the artist (ptkrkr, sculptor?) Hinzani (?), ordering them to let him "make statues (?), (ptkrn) [on] which there shall be horsemen [ ... ] a horse with its rider (prš... swsh ' $m$ rkbh)", as Hinzani "has done previously". The reference to the artefact and the commission to make more like it led some scholars to believe that equestrian sculptures did exist in Achaemenid court circles. ${ }^{67}$ Nevertheless, this inference is not necessary, and the relevant word in the letter $p t k r$ (ptkrn in plural) may mean "relief" (a foreign loanword, OPers. patikara-), as it is found in that sense on the Bisitun inscription. ${ }^{68}$ In this meaning, it is not a freestanding statue, but rather an image on material. Since the latter designation may also cover images on seals, it may be that Hinzani was in fact a seal-cutter, ${ }^{69}$ and that the "previous work" refers to a cylinder seal of Arshama, like the one known by impressions on sealings of letters. ${ }^{70}$ On that seal, one person is about to kill another with his spear, while their respective two horses stand nearby. Thus, Arshama may have commissioned a seal image of a horse and warrior, not a statue of a mounted rider. ${ }^{71}$

Furthermore, the horse does not appear to feature in freestanding portions of the palaces in Achaemenid monumental sculpture. The fragments of an animal protome capital, which was on top of a column of the great hall of Palace $S$ in Pasargadae, were believed by the excavator Ernst Herzfeld to be those of a horse. ${ }^{72}$ Yet, this is now uncertain. ${ }^{73}$ In fact, no horse-head capital has been found in any of the palaces. Apropos their relative absence in Persepolis, Root (2002, p. 206) notes that "in view of the importance of the horse, it may seem puzzling that the animal does not play a more evident role in the program of architectural sculpture at Persepolis".

In the visual representations of the different delegations bringing gifts in the east stairs of the Apadāna (Audience Hall) in Persepolis, all we see are riderless horses (below). One may imagine here a deliberate Achaemenid attempt to hint at the dual condition of the animal, at once stressing its importance as a symbol of the Empire in the form of a tribute, while suppressing the presentation of the nomadic horsemanship. ${ }^{74}$

All matters equine were of prime importance to the elite as reminiscence of the past reality of nomadic society, along with the honor it gave them. Evidence for the former pride and prestige that horse brought to the noble society can be found in various artefacts,

65 See (Stronach 2009, p. 233, n. 35): "prolonged Achaemenid excavations at the site have so far failed to produce additional evidence for the existence of equestrian royal figures". See (Tuplin 2010, pp. 104-5). This is grounded in an ideological difference between the Assyrian and the Persian images of power.

66 Ctesias relates ( $F G r H 688$ F 14.38) that after the suppression of the revolt of Inarus the Egyptian Sarsamas (in all probability Arsames) was appointed to be the satrap of Egypt. For the date of the rebellion's suppression see (Kahn 2008). The last dated letter in his correspondence is from 407 BCE. See (Allen et al. 2014) (available online: http://blogs.bodleian.ox.ac.uk/wp-content/uploads/sites/116/2013/10/Vol-2-intro-25.1.14.pdf, accessed on 9 May 2021). A commentary is available as volume 3. See (Root 1979, pp. 129-30; 2002, p. 207).

68 DB 4.71, 73, 77, 90; Elamite version DB El. 3.85: battikarum; cf. DNa.41.

69 As proposed by (Boardman 2000, pp. 134, 165, 243, n. 28).

70 Bodleian Library Oxford, Pell Aram. I-XV.

71 See (Stronach 2009, p. 230): "it is probably legitimate to conclude that Arshama was not in the habit of commissioning equestrian statues. Moreover, any specific bent of this kind, even on the part of a high-born Persian, would probably have attracted unfavorable royal notice". For a discussion on this letter, see (Driver 1965, pp. 32, 71-74; Tuplin 2014, pp. 100-7). The small iconography had other ways of circulating and was visible to a different public.

72 See (Herzfeld 1929, p. 11): "ein prachtvoller Pferdekopf"; see (Stronach 1978, pp. 57, 61-62, 73-74, pl. 33; Root 2002, p. 206).

73 As (Kawami 1986, p. 266), has shown convincingly, the fragment may belong to a sculpture of a goat and not to a horse.

74 One may point at an interesting opposite parallel: in reality, the ancient Israelites had war and chariot horses (cf. 2 Samuel 8: 3-4, 1 Kings 10: 28-29, 1 Chronicles 18: 3-4); this did not prevent them from still maintaining the prohibition, from the time before they wielded power, not to hold nor to breed horses (Deut. 17:16); see (Kelekna 2009, pp. 99-100). 
like theriomorphic metal and terracotta drinking vessels with the head of a horse. ${ }^{75}$ These are found in Iran from the time of the Teppe Hasanlu (level IV) settlement in northern Iran (1000 to 800 bce), as exemplified in a bronze vessel terminating in a horse's head. ${ }^{76}$ Other examples are two presumably fifth-century BCE painted, complete horse-shaped terracotta rhyta: one said to be from Maku, north-eastern Iran, and the other from Susa, both with painted saddlecloths. ${ }^{77}$ Three other specimens worth mentioning belong to the "horn" or "bent" rhyton variety, namely a fragmentary fifth- or fourth-century silver rhyton terminating in a horse's head, whose original provenance is unknown (Figure 6), ${ }^{78}$ a silver rhyton with a horse protome with legs under its body (Figure 7); ${ }^{79}$ and a silver rhyton with a horse-and-rider protome, uniquely formed as a sculptural group, with the horse's forelegs and hind-legs again tucked beneath (Figure 8). ${ }^{80}$ The latter two were discovered in 1968, as part of a hoard in a large jug hidden in ancient Erebuni, Urartu (now Armenia). The original date is unknown, but could be fifth- or fourth-century BCE Cappadocia or Western Armenia. ${ }^{81}$ In the case of the rider rhyton, it has been suggested that he was a satrap or a noble of the royal family. ${ }^{82}$

Some of the aspects of the noble Persian honor and status were perceived by the Greeks in the context of the Persian Wars. For instance, Herodotus relates (9.20) that during the Battle of Plataea, Masistius' horse had a golden bridle and that after the battle (9.70), the Tegeans found in the Mardonius's tent a beautiful bronze manger of his horse, which they dedicated later as an offering in the temple of Athene Alea. ${ }^{83}$ Evidence for the reality of Persian aristocratic horse races is found in another passage of Herodotus, in which Xerxes steeds defeated Thessalian horses; Xenophon narrates another horse race. ${ }^{84}$ Equestrian images were part of official seals, like the impressions of two found in the Persepolis Treasury. ${ }^{85}$ Xenophon (Cyr. 8.1.8) relates that the honorable men of rank (the है $v \tau \iota \mu \mathrm{o}$ ) came to their king's court with their horses and spears.

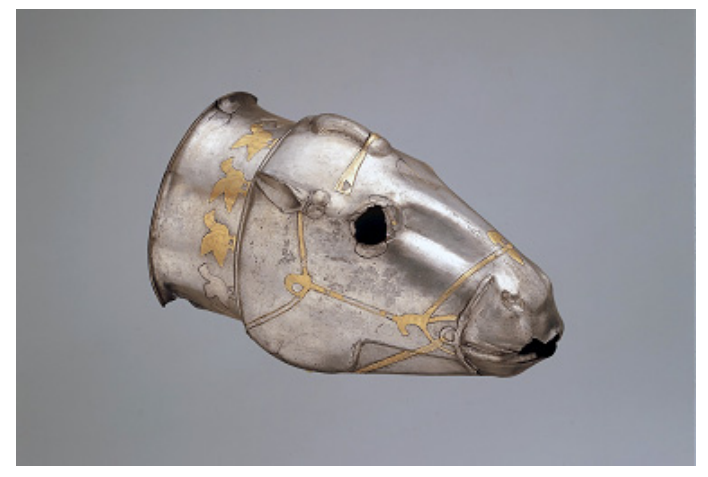

Figure 6. Vessel in shape of horse's head (MMA acc. no. 47.100.87); rhyton, gilded silver; Iran; Achaemenid, ca. 5th cent. BCE [image courtesy of the Metropolitan Museum of Art, New York].

5 See (Moorey 1985, p. 34): "thus, the taste for metal vessels of this form may be ultimately Iranian, as some of the favoured animals might indicate".

76 MMA acc. no. HAS 60-881; see (Dyson 1961, p. 537, fig. 10; Muscarella 1988, p. 24).

77 Respectively, INM inv. nos. 6700 and 8485; see (Curtis and Tallis 2005, p. 227, nos. 410, 411).

78 MMA acc. no. 47.100.87; for the provenance, see (Muscarella 1980, p. 30; Simpson et al. 2010, p. 434).

79 EHAM inv. no. 19; see (Treister 2015, pp. 27-39).

80 EHAM inv. no. 20; see (Stronach 2009, pp. 226, 230, fig. 11), who rightly dismisses the assertion of (Farkas 1974, p. 76), that there was no Persian horse and rider motif "until Greek artists created it"; see (Treister 2015, pp. 39-65, 95-99).

81 See (Stronach 2011, pp. 259, 263; Treister 2015, pp. 38, 60).

82 Orontes, satrap of Armenia after 401 BCE? This is speculative, as admitted by (Treister 2015, pp. 61, n. 137 and 64; Stronach 2009, p. 226): “a person of rank".

83 See (Kelekna 2009, p. 78): "metal items were not always strictly utilitarian. Designed to celebrate the nomadic lifestyle, many horse and chariot trappings and belt accessories [ ... ] were now rendered in bronze, silver, and gold".

84 Hdt. 7.196; Xen. Cyr. 8.3.25, Eq. 8.6; Strab. 11.13.7.

85 In the first seal impression, there are two mounted horsemen, in the second, one. Respectively, seal 18: (Schmidt 1957, p. 25, pl. 6, PT4 976, PT4 805) and seal 34 (Schmidt 1957, p. 31, pl. 10, PT6 179, PT6 40; Root 2002, p. 207). 


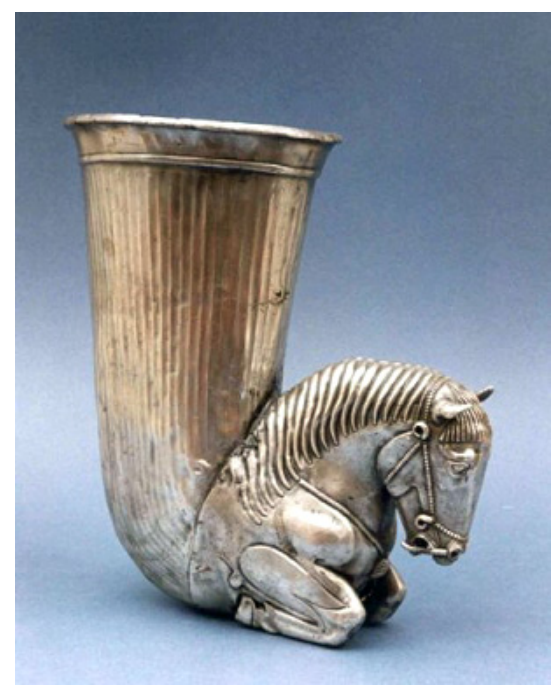

Figure 7. Drinking vessel in shape of horse protome (EHAM inv. no. 19); rhyton, silver; Erebuni, Armenia; (post?) Achaemenid, ca. 4th cent. BCE [image courtesy of the Erebuni Historical and Archaeological Museum-Reserve, Yerevan].

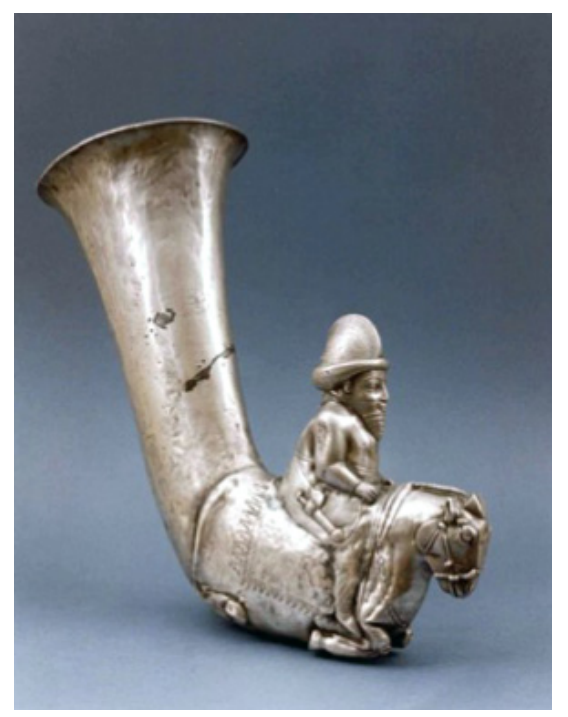

Figure 8. Drinking vessel in shape of horse with rider (EHAM inv. no. 20); rhyton, silver; Erebuni, Armenia; (post?) Achaemenid, ca. 4th cent. BCE [image courtesy of the Erebuni Historical and Archaeological Museum-Reserve, Yerevan].

Some items which display the interest of the elite in horses and horsemanship are problematic in that their date and provenance is unclear. One such artefact is a cast bronze figurine of a horse, galloping, and rider, leaning forward, probably originally attached to a (now missing) vessel (Figure 9). ${ }^{86}$ Other items are also challenging, since they come from a collection in which modern forgeries may be found. This is the so-called "Oxus Treasure" from central Asia, found between 1876 and 1880 and containing c. 180 gold and silver items of alleged Achaemenid metalwork, mostly votive offerings. ${ }^{87}$ Among the items is a gold figure of a male rider, originally mounted and holding reins, now extant without his horse (Figure 10). ${ }^{88}$

86 BM inv. no. 117760 (reg. no. 1890,0308.5); see (Curtis and Tallis 2005, p. 226, no. 409).

87 See (Dalton 1964, p. xvi; Curtis and Tallis 2005, pp. 47-48). For the date, see (Allen 2005, p. 98; Boardman 2006).

88 BM inv. no. 124098 (reg. no. 1931,0408.1); see (Curtis and Tallis 2005, p. 226, no. 408; Stronach 2009, p. 225) (who argues that the figurine "was intended to represent a notable personage-perhaps, in this case, a local satrap"). 


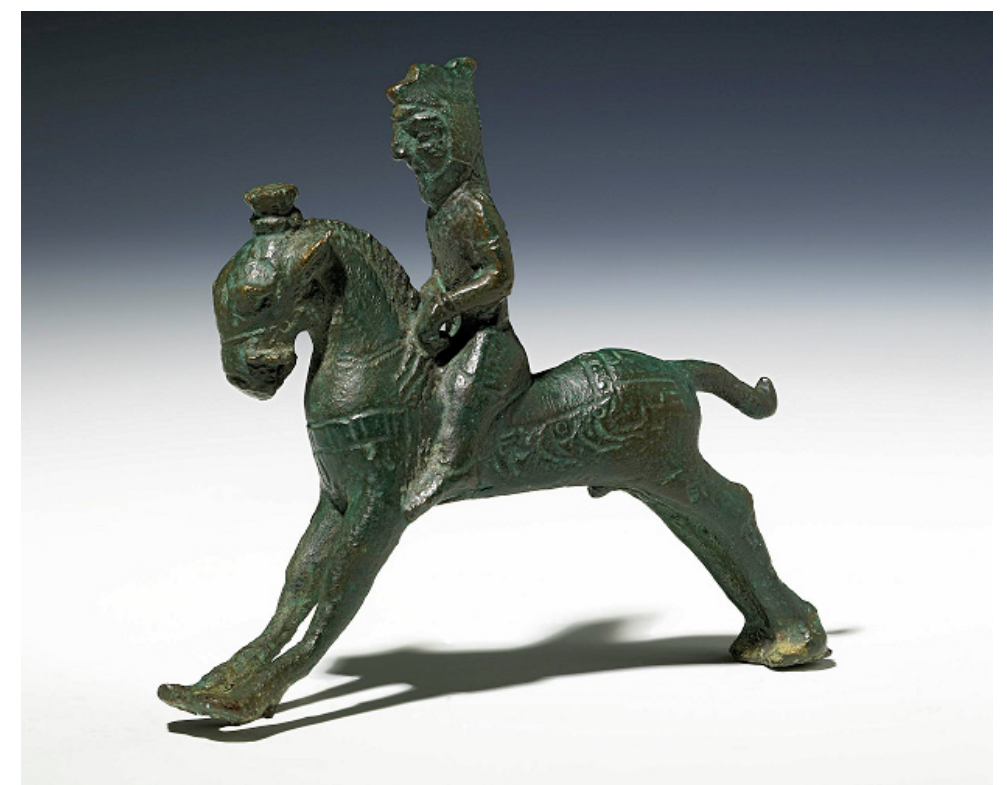

Figure 9. Mounted rider in Median dress (BM inv. no. 117760; reg. no. 1890,0308.5); statuette, bronze; found in Egypt (?); Achaemenid, ca. 5th-4th cent. BCE [image courtesy of the Trustees of the British Museum, London].

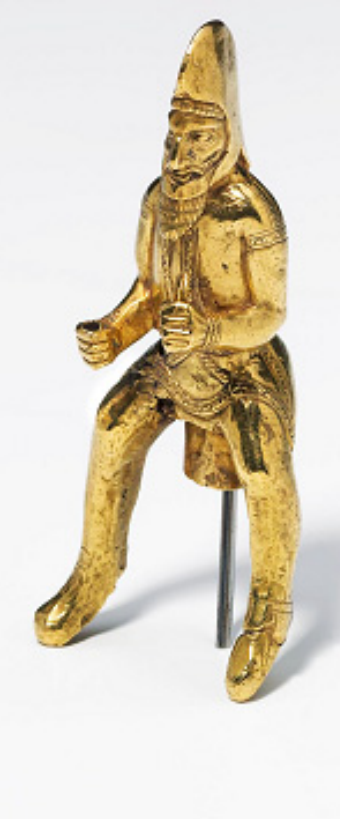

Figure 10. Rider wearing pointed cap (BM inv. no. 124098; reg. no. 1931,0408.1); figure, gold; found at Takht-i Kuwad (?) (Oxus Treasure), Tajikistan; Achaemenid, ca. 6th-4th cent. BCE [image courtesy of the Trustees of the British Museum, London].

In the Persepolis reliefs of the east stairs of the Apadāna, some delegates arrive bringing horses as gifts or tribute, with their manes knotted at the top and at the tip of 
their tails (Figure 11). ${ }^{89}$ This practice should rather be seen as part of the imperial and royal mechanism rather than the aristocratic pre-imperial appreciation of the horse. In the royal personnel, there were special people in charge of taking care of the horses, as evident in the Persepolis fortification tablets. ${ }^{90}$ A token of the imperial significance can also be seen in the gifts bestowed by the king upon his dignitaries. A few examples in Greek texts stress this importance. For instance, Xenophon in the Cyropaedia (8.2.8) asserts that certain gifts are "so readily recognised as some of those which the king gives" such as bracelets,

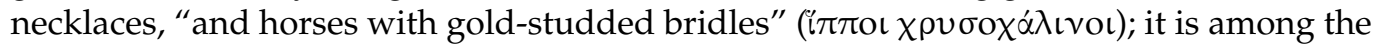
items that no one is allowed to have, except those to whom the king has given them. ${ }^{91}$ In a later passage, Cyrus gives a man:

one of the horses that were being led in the procession and [gives] orders to one of the macebearers to have it led away for him wherever he should direct. And to those who saw it, it seemed to be a mark of great honour, and as a consequence of that event many more people paid court to that man. ${ }^{92}$

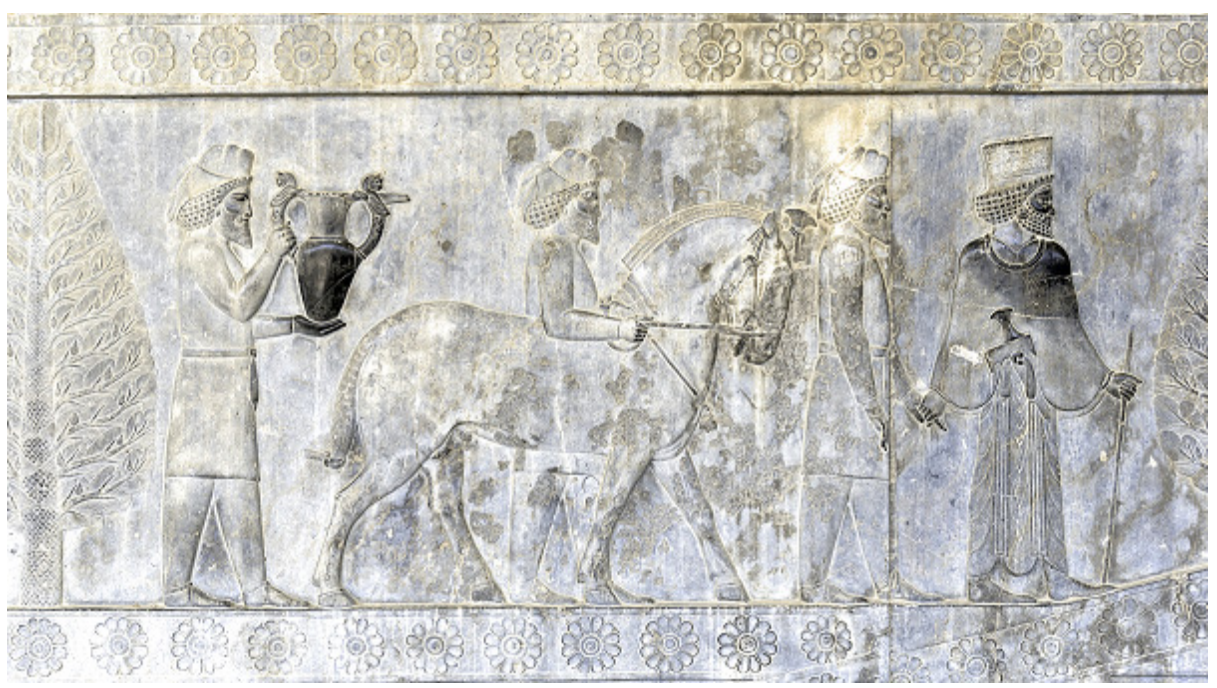

Figure 11. Armenian delegation leading a horse; relief scene; Apadana, Persepolis, Persia (mod. Iran); Achaemenid, ca. 518-486 BCE [photography by Peter Udom; courtesy of Shutterstock].

Indeed, in the Anabasis (1.2.27), as part of the royal aspirations displayed by Cyrus the Younger, he gives the Syennesis of Cilicia gifts, "which are regarded at court as tokens of honour", among them, a gold necklace and bracelets, a gold dagger and "a horse with a

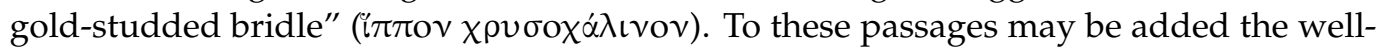
known depiction in Esther (6:1-9) of the royal gift of a horse. ${ }^{93}$ In this practice, we can see the combination of a vestige from the value system of the nomadic community, a society of warriors, which attached great importance to horses on the one hand, and the imperial hierarchical structure adopted later on, with its focus on the great ruler, on the other. The result was a system, which prized horses yet gave the king a prerogative in determining

89 For example, delegations identified as Armenians (No. 3), Cappadocians (No. 9), Scythians (No. 11), Sagartians (No. 16), Sogdians (No. 17) and Thracians (No. 19) bring horses, while dignitaries or guards introduce free horses and/or horse-drawn chariots; BM inv. nos. $118842-43$ (reg. nos. 1818,0509.1-2); see (Schmidt 1953, pls. 29, 35, 37, 42, id. 1957, pl. 52; Barnett 1957, p. 61, pls. 15.3, 16.4, 17.1, 18.1; Walser 1966, pp. 74-75, pls. 10, 36, 39; Afshar and Lerner 1979; Mitchell 2000, p. 51, pl. 22.a-b; Curtis and Tallis 2005, p. 70, no. 25; Gabrielli 2006, pp. 5-34).

90 PF inv. nos. 1668-69, 1675, 1765, 1784-87, 1793, 1942; cf. PFa 24, 29; see (Briant 2002, pp. 426, 457, 1023).

91 Cf. Luc. Quom. hist. consc. 39 on the Nisaean horse.

92 Xen. Cyr. 8.3.23, trans. adapted from Miller (LCL series).

93 Est. 6:7-9: "For the man whom the king delights to honor, let a royal robe be brought which the king has worn, and a horse on which the king has ridden, which has a royal crest placed on its head. Then let this robe and horse be delivered to the hand of one of the king's most noble princes that he may array the man whom the king delights to honor. Then parade him on horseback through the city square, and proclaim before him: 'Thus shall it be done to the man whom the king delights to honor!"'. 
the nature of the honors and the bestowal of them to a selected few. An example of this amalgamation is Xenophon's presentation, according to which the establishment of the Persian cavalry had to do with the honor the nobles received from Cyrus when he gave them horses. ${ }^{94}$

The last aspect to note with regard to the horse in Persia is its role in religious rites, where it was sacrificed in honor of the sun. Such rites, found in Greek literature, ${ }^{95}$ attest to the importance attached to the horse, which presumably goes back to a society in which it was prized above cattle and other animals known in agricultural sedentary societies. The practice of horse sacrifice was Indo-Iranian, while the association of steeds and the sun goes back to the Avestan society, where horses pull the celestial body's chariot. ${ }^{96}$ Curtius Rufus (3.3.11) refers to a large horse in Darius III's procession as "the steed of the sun" (equus, quem Solis appellabant). A similar ritual is also known in the form of sacrifices around the tomb of Cyrus the Great:

Within the enclosure, and lying on the approach to the tomb itself, was a small building put up for the Magians, who were guardians of Cyrus' tomb, from as long ago as Cambyses, son of Cyrus, receiving this guardianship from father to son. To them was given from the king a sheep a day, an allowance of meal and wine and a horse each month, to sacrifice to Cyrus. ${ }^{97}$

Furthermore, Herodotus (3.90) states that Cilicia had to supply 360 white horses to the

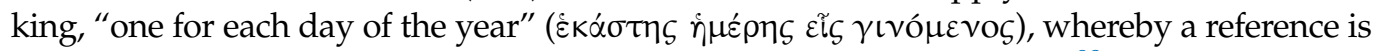
made to the lunisolar year of 360 days (including five epagomenal days). ${ }^{98}$ In the description of Strabo, the satrap of Armenia sent 20,000 horses to the Great King for the feasts of Mithra each year. ${ }^{99}$ This tradition ties together the rite of the sacrifice of horses to the sun ${ }^{100}$ with the imperial tribute system. In that system, payment was also made in horses: the Cappadocian annual tribute to the Persians was 1500 steeds, 2000 mules, 50,000 sheep. ${ }^{101}$ Compare the realistic figures, which Xenophon (Anab. 4.5.24) reports: a certain village reared seventeen horses for tribute to the Persians. The Persians followed their imperial Assyrian predecessors in levying horses. ${ }^{102}$ This self-projected imperial image is presumably the reason for the stress on the cavalry and horse breeding of other nations (mostly Iranian) than the Persians, seen in the Apadāna reliefs (above) and in Greek texts. ${ }^{103}$ It would seem, therefore, that the Persians were able to incorporate a traditional, nomadic set of values, in which the horse played an important part (and hence religious as well), within an imperial system in which they controlled many sedentary populations of the empire and exacted from them a tribute in steeds, presumably for military objectives. ${ }^{104}$

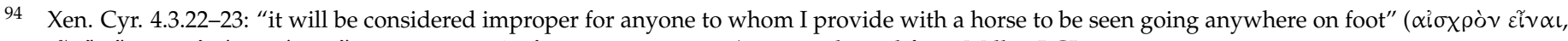

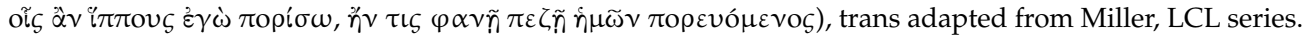

95 See Xen. Anab. 4.5.35; Cyr. 8.3.12, 24; Paus. 3.20.4; Philost. VA 1.31; cf. Hdt. 1.216, on the Massagetae, and also (Briant 2002, pp. 94-96, 245-46, 281) on Hdt. 1.189-90; see (Boyce 1975, pp. 122, 151). Cf. a Persian sacrifice of a horse to water at the river Strymon (Hdt. 7.113), cf. Tac. Ann. 6.37 (Parthian).

96 Yasna 1.11, 4.16, 7.12, 16.4, 22.24, 25.4, 68.22, Yasht 10.13, 90, 125, 136, 6.1, 4, 6-7, 12.34, 13.81; cf. RgVeda 1.162 (horse sacrifice); Yasht 10.52, 66, 68, 76 (Mithras); Just. 1.10.5; see (Aalto 1975, pp. 8-9; Frye 1984, p. 55; Kelekna 2009, pp. 113-15).

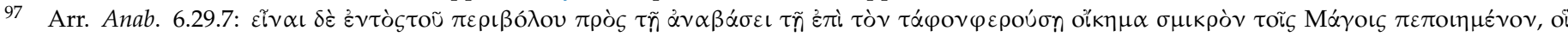

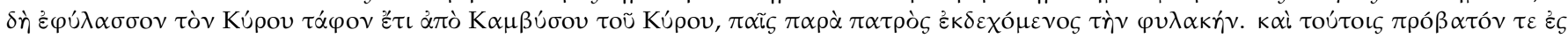

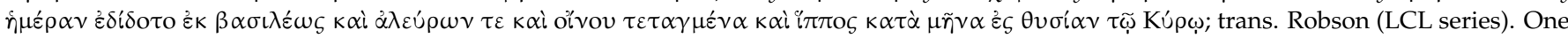

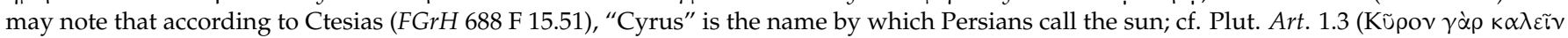

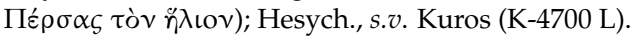

98 See (Taqizadeh 1938, pp. 13-16).

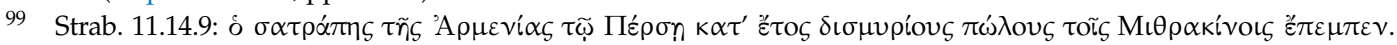

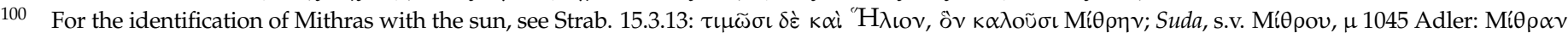

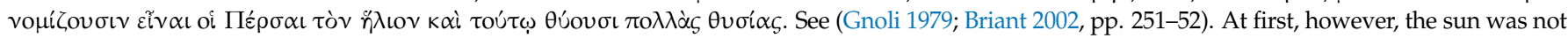
associated with Mithras: see Yasna 1.11.

101 See Strab. 11.13.8.

102 Cf. Assyrian records of Median horse tribute (Luckenbill 1926, p. i.786, no. 795; Starr 1990, no. 66.2-5, 71.3-5; Roaf 1995, pp. 59-61; Radner 2003, pp. 45, 54).

103 See (Tuplin 2010, pp. 153-56).

104 See (Tuplin 2010, pp. 138-39), who assumes that the tribute "represents an equine resource for military purposes", but readily admits (n. 158) that the "levying of white horses might reflect a different agenda". 


\section{The Lion}

The typical prey of hunting scenes and depictions in the Ancient Near East was the lion (Panthera Leo). An large early Mesopotamian basalt stone slab from the fourth millennium BCE portrays the assumed ruler of Warka (Uruk) fighting lions in two positions, one as shooting an arrow and another as throwing a spear (Figure 12). ${ }^{105}$ Undeniably, very early in the Ancient Near East, one of the responsibilities of the ruler was to meet and avert the danger of beasts to the population. ${ }^{106}$ The hunt was thus a symbol of the primeval clash between orderly society and the powers wishing to destroy it, symbolized by the lion. ${ }^{107}$ Because of this honor and duty of the leader to chase the lion, that animal was increasingly connected with majestic influence and might. ${ }^{108}$ King Shulgi (2075-25 bce) compares himself to a lion, therefore insinuating that the features of the lion and his fierceness are absorbed by the hero who overcomes it. ${ }^{109}$ The hunt was an opportunity for the king to display an almost heroic personal involvement in the killing of animals, sometimes with his own bare hands. Tiglath-Pileser I (c. 1100 bce) boasts of killing 120 lions on foot and 800 from his chariot. ${ }^{110}$ Adad-Nirari II (911-892 BCE) claims to have killed 360 lions from his chariot. ${ }^{111}$ Ashurnasirpal II claims he killed no less than 450 great lions and 390 wild bulls.

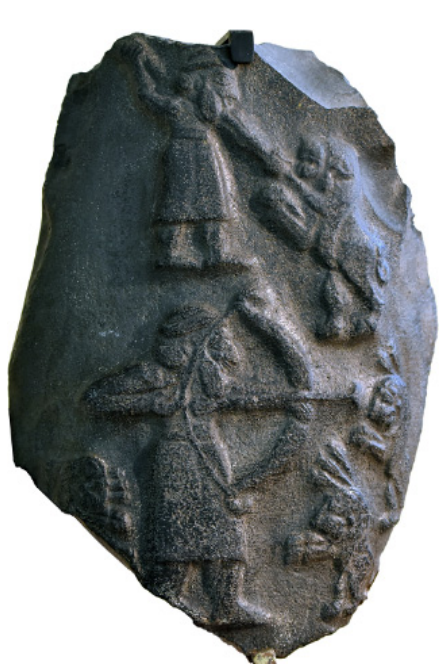

Figure 12. Lion hunt scene (IrMus inv. no. IM 23.477); basalt relief; Uruk, Southern Mesopotamia (mod. Iraq); Jemdet Nasr period, ca. 4th mill. BCE [photography by Osama Shukir Muhammed Amin; courtesy of the Ancient History Encyclopedia].

The famous Neo-Assyrian instances of the lion hunt are reliefs from the Northwest Palace at Nimrud (9th cent. BCE) featuring King Ashurnasirpal II or the crown prince Shalmaneser III (Figure 13; cf. Figure 2). ${ }^{112}$ Then, for almost two hundred years, this hunting theme appears only in depictions in royal seals (Figure 14). ${ }^{113}$

105 IrMus inv. no. IM 23.477; see (Watanabe 2002, p. 42).

106 See (Frankfort 1954, p. 78).

107 See (Watanabe 2002, p. 83; Strawn 2005, pp. 141-50).

108 See (Watanabe 2002, pp. 42-56). For different explanations, see (Root 2002, p. 198): "this related in part to the simple reason that the lion was observable as a powerful and beautiful wild animal" and on p. 200: "the lion maintained a special place, respected for its lack of fear and therefore associated with royalty".

109 See (Pritchard 1969, pp. 585-86, lines 3, 14, 43, 71; Cornelius 1989, pp. 58-59; Watanabe 2000; Strawn 2005, pp. 152, 161, 174-84) for more references. The theme was most popular in Egypt. The ferocity of the lion was believed to be absorbed by the hero who overcame it.

110 See (Wiseman 1952, lines 86-94; Luckenbill 1926, pp. i.85-6, nos. 247-48).

111 See (Luckenbill 1926, pp. i.116, no. 375).

112 BM inv. no. 124579; see (Curtis and Reade 1995, no. 5).

113 BM inv. no. 84672 (reg. no. 1851,0902.191); cf. BM reg. nos. 84672, K 391; see (Sachs 1953). 


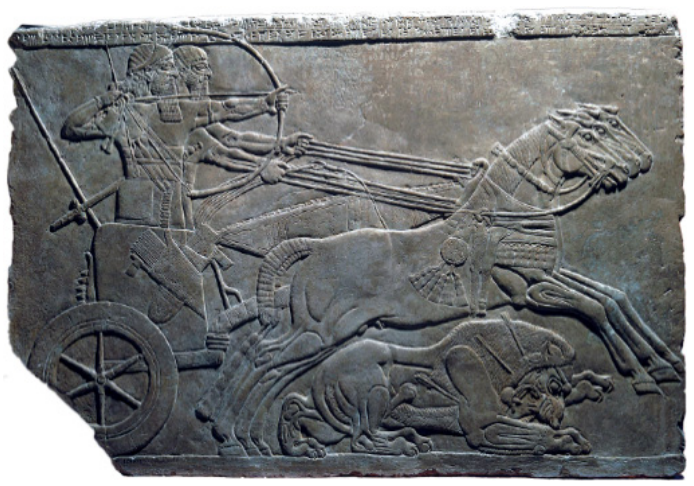

Figure 13. Ashurnasirpal II (or Shalmaneser III) hunting lions (BM inv. no. 124579; reg. no. 1849,1222.8); gypsum relief; Northwest Palace, Nimrud (mod. Iraq); Neo-Assyrian, ca. 865-860 вCE [image courtesy of the Trustees of the British Museum, London].
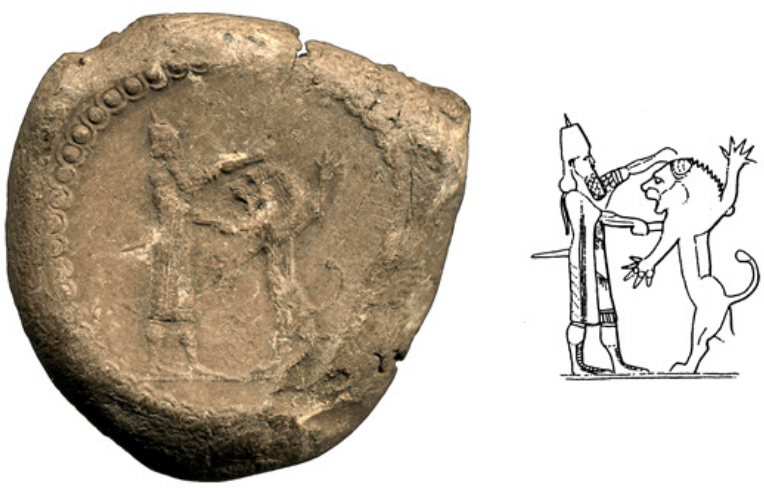

Figure 14. King slaying lion (BM inv. no. 84672; reg. no. 1851,0902.191); clay seal impression; Nineveh (mod. Iraq); Assyrian, ca. 9th-8th cent. BCE; with line drawing [image courtesy of the Trustees of the British Museum, London].

Only in the seventh century BCE was it performed before spectators, ${ }^{114}$ in particular in the Nineveh (north palace) royal hunt scenes of Ashurbanipal. ${ }^{115}$ The reliefs of the latter are the prominent portrayals we have of lion hunting in the Ancient Near East. They present a dramatic re-enactment of a chase, and are meant to highlight this element in the royal Neo-Assyrian ideology. They are unrealistic, for instance, in the display of the king Ashurbanipal seizing a lion by the tail with his left hand (Figure 15). ${ }^{116}$ In the final stage of Ashurbanipal's hunting scenes, which is now in the Louvre Museum, the lion is facing the king, who drives his spear in it. ${ }^{117}$ This also appears in one of the reliefs now in the British Museum where the king dispatches a lion with sword (Figure 16). ${ }^{118}$ On the other hand, there are realistic aspects in the reliefs, in that they show that the king was not alone in the orchestrated chase. There is a religious dimension here as well. The hunt may be a battle between Ashur and the incarnate hosts of evil, the lions, led by Tiamat. ${ }^{119}$ In another register of the same relief, Ashurbanipal is seen pouring a wine libation over the bodies of four lions (Figure 17). ${ }^{120}$

114 Collon 1995, n. 188, see (Weissert 1997, p. 356; Reade 1998, p. 77).

115 See (Albenda 1972, 1974; Watanabe 1992, 2002, pp. 76-78, 80).

116 BM inv. no. 124886 (reg. no. 1856,0909.51: central register from Room S of the North Palace); see (Frankfort 1954, pl. 108b; Barnett 1976, p. 54, pl. 57; Curtis and Reade 1995, Nos. 28-29; Strawn 2005, pp. 163-65).

117 Louvre inv. no. AO 19903 (Nineveh, North Palace, Room S).

118 BM inv. no. 124874 (reg. no. 1856,0909.48: top register from Room S of the North Palace); cf. BM inv. no. 124875 (Nineveh, North palace, Room S, Panel 11: Ashurbanipal on horseback killing lion with spear); see (Frankfort 1954, pl. 113; Barnett 1976, p. 51, pl. 49).

119 See (Strawn 2005, nn. 170-71).

120 BM inv. no. 124886 (reg. no. 1856,0909.51: lower register from Room S of the North Palace); see (Frankfort 1954, pl. 108b; Barnett 1976, p. 54, pl. 57; Curtis and Reade 1995, Nos. 28-29; Strawn 2005, pp. 163-65). 


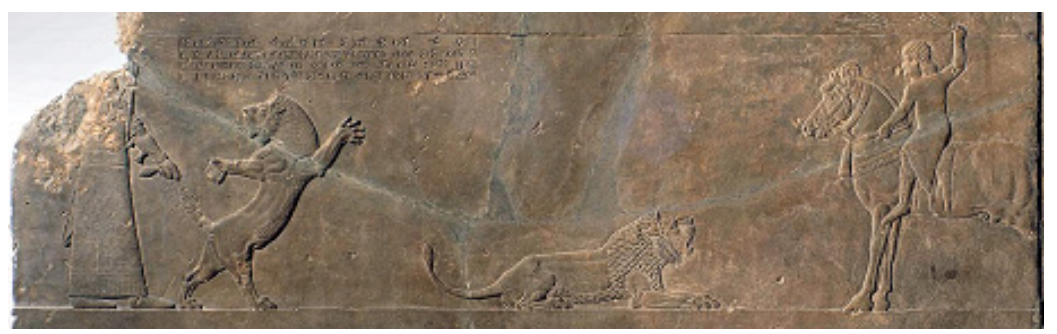

Figure 15. King Ashurbanipal grabbing lion by its tail, ready to strike (BM inv. no. 124886; reg. no. 1856,0909.51); gypsum relief; North Palace, Nineveh (mod. Iraq); Neo-Assyrian, ca. 645-635 вCE [image courtesy of the Trustees of the British Museum, London].

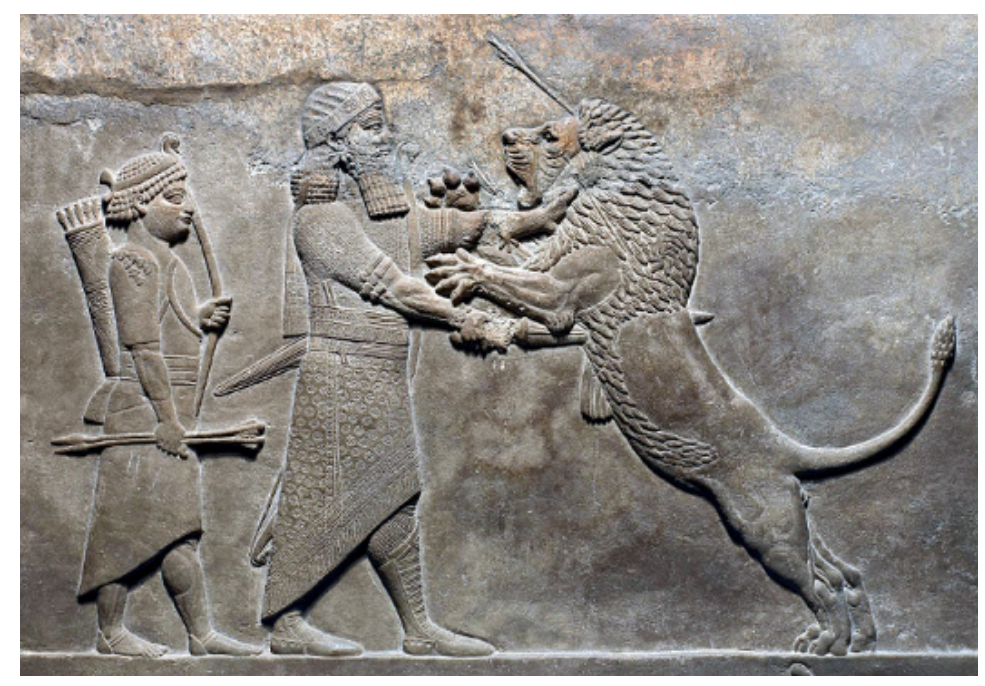

Figure 16. King Ashurbanipal on foot killing a lion with sword (BM inv. no. 124874; reg. no. 1856,0909.48); gypsum relief; North Palace, Nineveh (mod. Iraq); Neo-Assyrian, ca. 645-635 вCE [image courtesy of the Trustees of the British Museum, London].

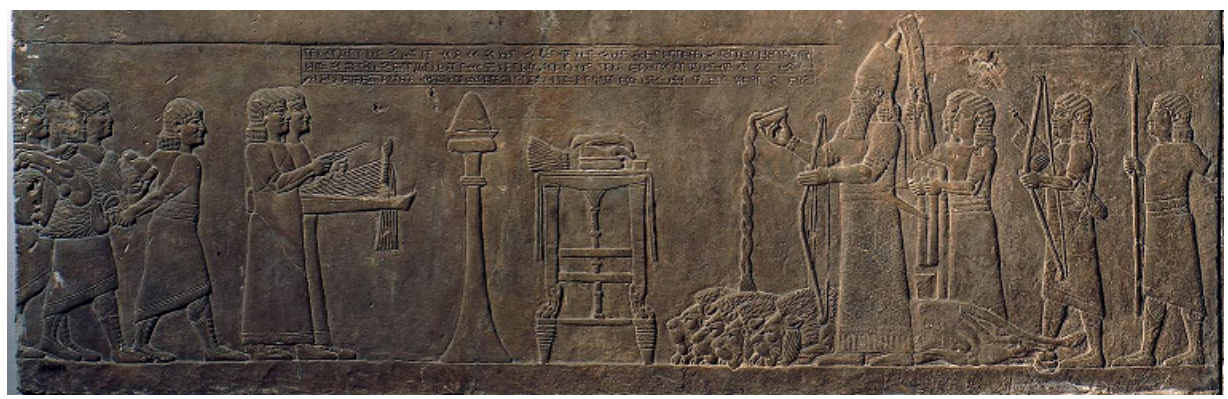

Figure 17. King Ashurbanipal pouring wine libation over four dead lions, surrounded by attendants (BM inv. no. 124886; reg. no. 1856,0909.51); gypsum relief (lower register); North Palace (Room S), Nineveh (mod. Iraq); Neo-Assyrian, ca. 645-635 вCE [image courtesy of the Trustees of the British Museum, London].

The hunt, and in particular lion hunting, occupies a problematic and ambiguous place within the Achaemenid court once the Persians succeed the Assyrians (and following the Neo-Babylonians) as dominating a world empire. One attitude can best be described as a deliberate attempt to suppress, in monumental Achaemenid sculpture, the traces of the lion hunt as it evolved in imperial Assyrian times. It is known that the hunting theme in Ancient Persia is absent from the portrayals of the Achaemenid king in the reliefs of the palaces. This absence is not merely because of the state of archaeological discoveries; similarly, there is no evidence of the theme in the royal inscriptions. Given that the hunting 
imagery was generally conspicuous in the ancient world, we can comprehend the reason why Greek writers felt the need to insert it into their readings of the Achaemenid inscriptions. Onesicritus, for instance, as Strabo (15.3.8) quotes him, indeed has the following text of an inscription on Darius' grave: "as hunter I prevailed". The phrase is either a misunderstanding of the actual legend or intended Greek embroidery. ${ }^{121}$ The iconographic and inscriptional silence concerning hunting in the Achaemenid period is unexpected since Neo-Assyrian pictorial inspiration on Persian imagery is evidenced elsewhere. ${ }^{122}$ It would seem to be a fair inference that the royal Achaemenid representations purposefully repressed any hint of the theme of the hunt.

The source for this suppression is probably twofold. Firstly, the lion had a religious significance and power in Elam, and among the Iranians at large. As presentations of the Elamite goddess Narundi were influenced by the imagery of the Sumerian, Akkadian, Babylonian and Assyrian goddess of love and war, Inanna/Ishtar, ${ }^{123}$ the latter's attribute of the lion was also appropriated by Narundi. This is evidenced in a statue of her throne from Susa (Figure 18). ${ }^{124}$ Dedicated by king Puzur-Inshushinak (r. c. 2100 bce), king of Awan and ruler of Susa, this statue has six guarding lions on all sides: at her feet are two reclining lions facing each other; at the back, two standing upright and holding staffs as entrance guardians. ${ }^{125}$ A later token of this association between lions and the Mesopotamian goddess is the presence of lions on the walls of the processional street from the Ishtar Gate at Babylon (built $575 \mathrm{BCE}$ ). ${ }^{126}$ This protective function is noticed in Iran in the gate decoration said to come from ancient Ecbatana (Hamadan), Media, which has a procession of embossed figures of winged lions. ${ }^{127}$ A winged lion may serve the same apotropaic purpose in a gold horn rhyton, also said to be from Ecbatana. ${ }^{128}$ Another example from Susa is the twelfth-century BCE monumental, $1.3 \mathrm{~m}$ in height, glazed terracotta sculpture of a lion (out of an original pair) guarding the entrance to the Temple of Inshushinak (Figure 19). ${ }^{129}$

Secondly, in the eastern lands controlled by the Achaemenid monarchy, the lion hunt was perhaps remembered as one of the features of the Assyrian imperial reality and selfrepresentation, and was perhaps identified too closely with it. The grand coalition that defeated Assyria and occupied Nineveh (612 BCE) included Medes and Elamites. It is probable that a few soldiers of these groups were the ones who mutilated some of the Neo-Assyrian royal hunting icons in the reliefs. Two acts of disfigurement in particular involve damage to the grasp the king has of a lion: in one, the tail is hewed (Figure 15) ${ }^{130}$ in the other, the monarch's hands are mutilated, the right one piercing the lion and the left strangling it (Figure 16). ${ }^{131}$ In both cases, it would appear that there was an attempt to "free" the lion, as it were, from the Assyrian imperial hold. ${ }^{132}$ This would imply an aversion to the hunting iconography.

121 See (Schmitt 1988, p. 29).

122 See (Porada 1965, p. 162; Cremer 1984, pp. 92-95).

123 OIM reg. no. A27903 (acc. no. 2953: black limestone cylinder seal; unknown provenance (mod. Iraq); Akkadian, ca. 3rd mill. BCE): depicting Ishtar-Inanna with foot on back of lion; see (Seidl 1989, p. 139; Watanabe 2002, pp. 90-91; Collins 2009, pp. 23-24).

124 Louvre inv. nos. Sb 54-Sb 6617; see (André-Salvini 1992).

125 A guardian lion also originally appeared on a votive foundation bolder dedicated by Puzur-Inshushinak, designed to protect a building, now in fragments (Louvre inv. no. Sb 6, 177). Only the nose and a claw of the lion at the left side remain (Amiet 1966, pp. 223-29).

126 Cf. Vorderasiatisches Museum, Berlin, VA 1392, 1408-56. See (Strawn 2005, p. 224): "the lion lends its protective force to the entirety of the city".

127 INM inv. no. 1392; see (Curtis and Tallis 2005, p. 98, no. 85).

128 INM inv. no. 1321; see (Curtis and Tallis 2005, p. 121, no. 118).

129 Louvre inv. no. Sb 2716; see (Amiet 1966, pp. 524-25; Root 2002, p. 200).

130 Central register of Ashurbanipal's hunting relief (BM inv. nos. 124886-87).

131 BM inv. no. 124874; see (Almagor forthcoming).

132 See (Curtis and Reade 1995, no. 28-29). According to (Razmjou 2018, p. 353), Ashurbanipal's lion hunting had such a strong symbolism, that the lions may actually stood in for his enemies in Elam. 


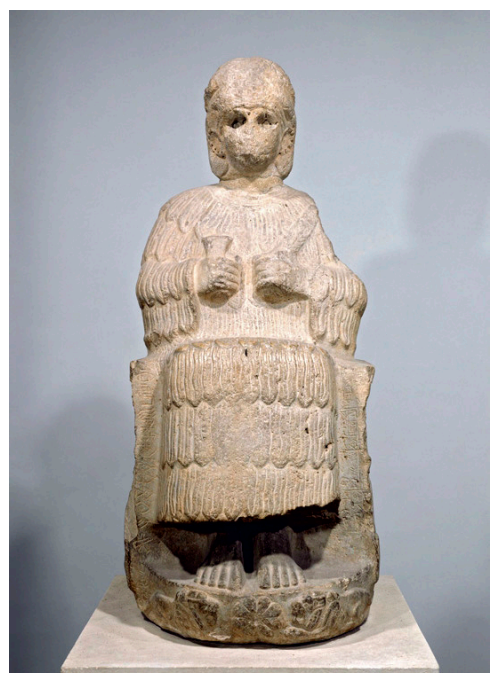

(a)

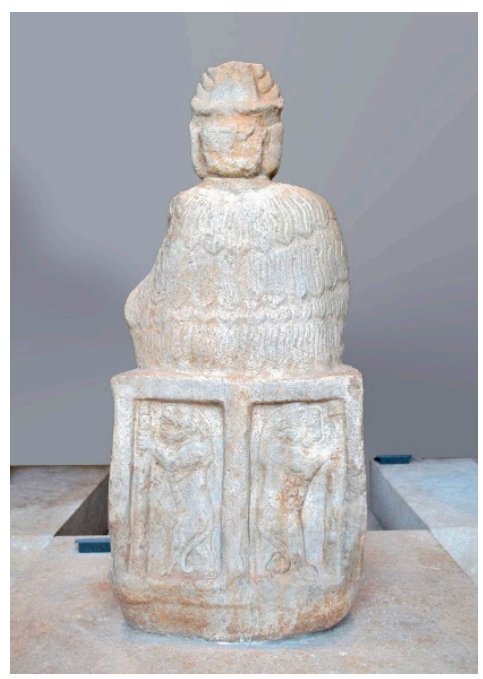

(b)

Figure 18. Enthroned goddess Narundi (Louvre inv. nos. Sb 54+6617), front and back (with snarling lions); limestone sculpture; Susa, Elam (mod. Iran); reign of Puzur-Inshushinak, ca. 2100 BCE [photography (a) by Pierre and Maurice Chuzeville; courtesy of the Louvre Museum, Paris; (b) by Darafsh Kaviyani; CC BY-SA 3.0 License].

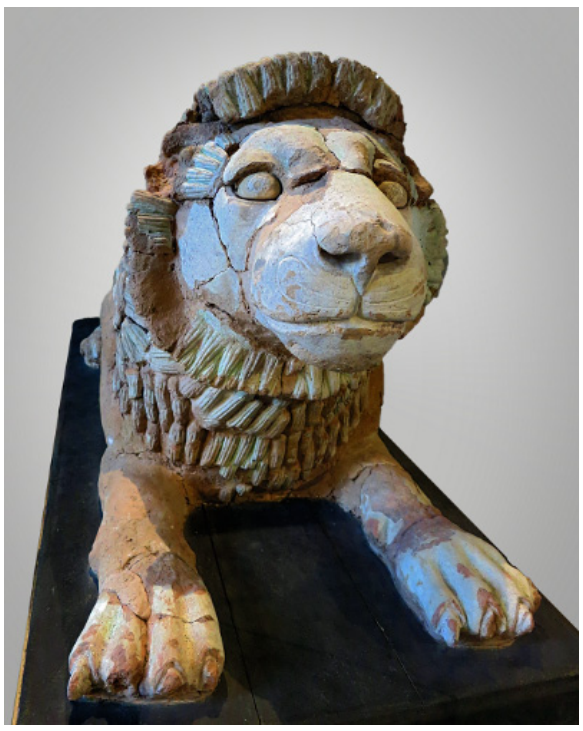

Figure 19. Recumbent guardian lion (Louvre inv. no. Sb 2716); glazed terracotta sculpture; Susa (Acropolis), Elam (mod. Iran); Elamite, 14th-12th cent. BCE [photography by Karl Steel; CC BY-NCSA 2.0 License].

This lion's importance to the Iranians would account for its appearance in numerous manifestations throughout Iran. Indeed, as Root (2002, p. 199), aptly describes it, "at Persepolis itself, the lion [ ... ] seems to be everywhere". Lions appear both as freestanding figures and on the reliefs. It may be that the two reclining headless feline grey limestone statues were originally lions, though the first excavators identified them as leopards. ${ }^{133}$ Yet, the most obvious example of the guardian lions placed at gates or doorways ${ }^{134}$ is the symplegma of the lion attacking a bull repeated on the reliefs of the façades of certain

133 OIM reg. no. A24077 (acc. no. 2110: grey limestone statue; Persepolis, Persia; Achaemenid, ca. 550-330-BCE); see (Schmidt 1957, p. 70, pl. 36; Root 2002, p. 200).

134 See (Strawn 2005, p. 225). 
buildings in Persepolis. The lion attacks at the rear, biting the bull's back, while the latter has its head turned back towards the lion. It is found, for example, in the triangle panels flanking the central groups of guards on the southern section of the central façade of the eastern stairway (Figure 20), ${ }^{135}$ and in palace H (Figure 21). ${ }^{136}$ This is a known iconographic type, which goes back to Mesopotamian and Anatolian art. ${ }^{137}$ Several explanations have been suggested for this symbolic struggle, such as the symbolism of good vs. evil (in this case, the lion protects against the perilous bull) or, less likely, a symbolic union (between the powers of the sun and the moon). ${ }^{138}$ A reasonable understanding of this symbol is to consider the two animals as tokens of their constellations (Leo, Taurus), indicating their relative positions in the vernal equinox. ${ }^{139}$ This date coincides with that of the Zoroastrian New Year (the Nowruz), probably the occasion for the tribute procession depicted in the reliefs. ${ }^{140}$

Among the lion artefacts in Persepolis, whose role may be supposed to be apotropaic ${ }^{141}$ and are worthy of mention, the following are of note: the decoration of lions on the edges of the royal robes (Figure 22), ${ }^{142}$ which may go back to the function fulfilled by the bronze reclining lion-shape pins from ninth-century BCE Hasanlu (level IV) (Figure 23); ${ }^{143}$ a miniature gold lion striding to the right from Persepolis; ${ }^{144}$ the three-lion bronze pedestal whose original function is unclear (Figure 24); ${ }^{145}$ and a vessel with leonine legs. ${ }^{146}$

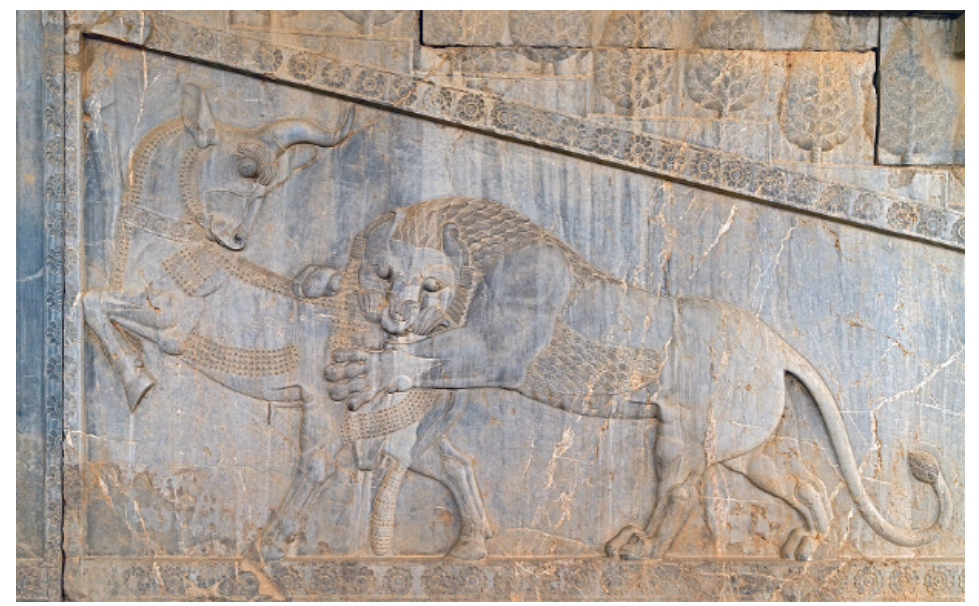

Figure 20. Lion attacking bull; relief panel; Apadana, Persepolis, Persia (mod. Iran); Achaemenid, ca. 518-486 BCE [photography by Janos Rautonen; courtesy of Shutterstock].

135 See (Schmidt 1953, pl. 19) (Apadana, eastern stairway); cf. ibid. pls. 20 (eastern stairway, southern section), 53 (northern stairway), 61 (northern stairway, west wing), 62 (Council Hall, main stairway), 66 (main stairway, east wing), 69 (main stairway, west wing), 126 (Tachara, Palace of Darius), 153a (western stairway, southern end), 159 (Palace of Xerxes), 161 (western stairway, southern flight), 166 (eastern stairway), 169a (eastern stairway), and 203d (Palace H).

136 OIM reg. no. A73100 (fragment of west portion of façade); see (Schmidt 1953, pl. 203).

137 For example, Museum of Fine Arts, Boston, acc. no. 48.1318 (decorated bronze shield boss; Khorsabad; 8th cent. BCE); see (Hartner 1965, p. 1).

138 See (Root 2002, pp. 201-3).

139 See (Hartner and Ettinghausen 1964, pp. 161-64; Hartner 1965, pp. 15-16): in the starry heaven of c. 4000 BCE, Lion was at Zenith and Taurus invisible below the horizon.

140 See (Herzfeld 1941, p. 251; Schmidt 1953, pp. 83, 107).

141 See (Strawn 2005, pp. 224-25).

142 See (Schmidt 1953, pl. 142a) (Tachara, Palace of Darius, western doorway in the north wall of the main hall).

143 MMA acc. no 61.100.10; see (Marcus 1994, p. 11) (interpreting the ornaments as "symbols of security, providing women with personal protection (magical and physical) both in daily life and in the underworld)"; see (Root 2002, pp. 198-9; Muscarella 2004, p. 707, fig. 11). Sixty such pins have been excavated, mostly in the so-called Burned Building II.

144 INM inv. no. 2351; see (Schmidt 1957, p. 77, fig. 14B; Curtis and Tallis 2005, p. 147, no. 190). Cf. the striding lion gold plaque in the BM. inv. no. 132108.

145 IMN old inv. no. PT5 642; see (Schmidt 1957, p. 69, pl. 33; Cahill 1985, p. 384, fig. 2).

146 IMN old inv. no. PT5 10 (green chert tripod bowl with leonine legs; Treasury (Hall 39, Persepolis; Achaemenid, ca. 550-330 BCE); Schmidt 1957, p. 89, pl. 55.3, (intended for ritualistic purposes?). 


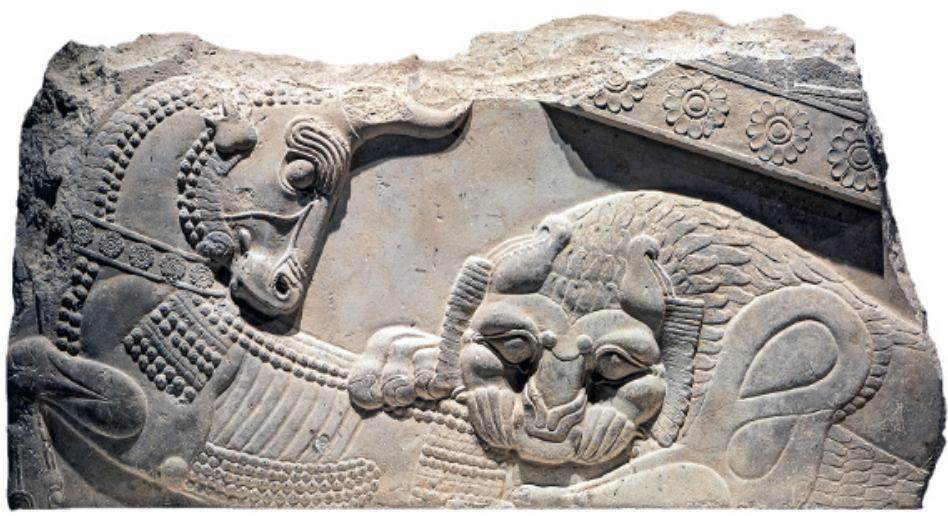

Figure 21. Lion attacking bull (OIM reg. no. A73100); relief panel, fragment; Palace H, Persepolis, Persia (mod. Iran); Achaemenid, ca. 404-358 BCE [photography by Michael Tropea; courtesy of the Oriental Institute Museum Chicago].

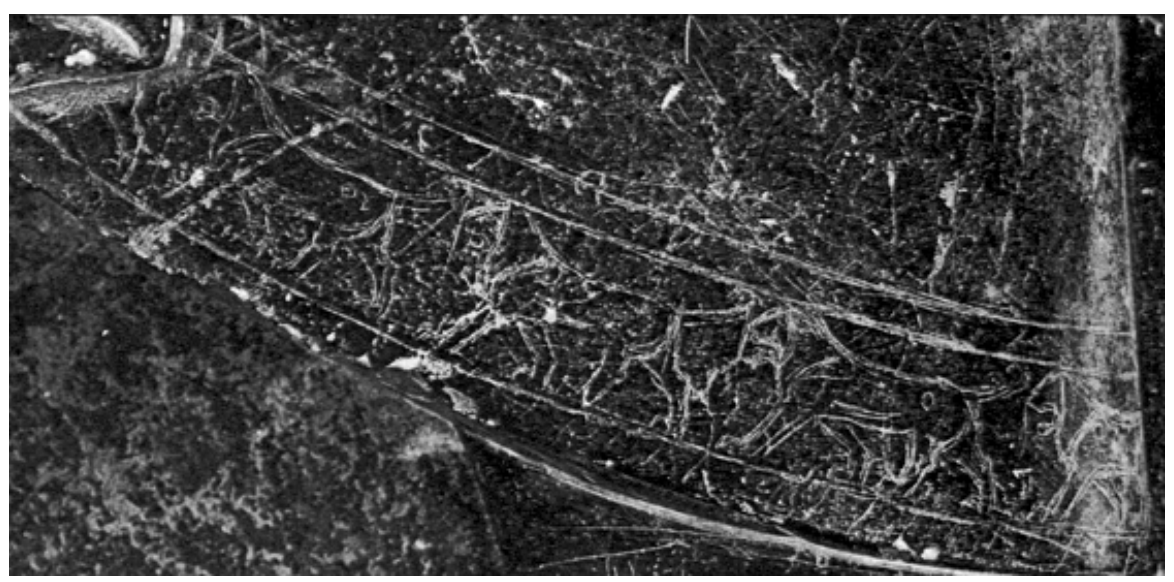

Figure 22. Design of lions on hem of Great King's gown; relief, detail; Palace of Darius, Persepolis, Persia (mod. Iran); Achaemenid, ca. 518-486 BCE [image taken from Schmidt (1953), pl. 142a; courtesy of the Oriental Institute, University of Chicago].

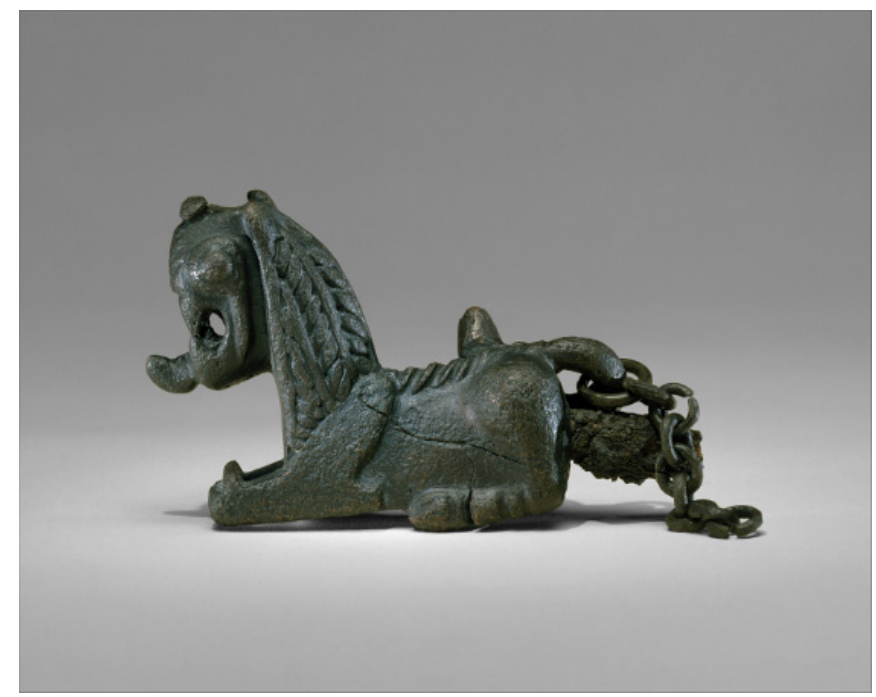

Figure 23. Garment (?) pin in form of lion (MMA acc. no 61.100.10); bronze ornament; Hasanlu, Iran; Iron Age II, ca. 9th cent. BCE [image courtesy of the Metropolitan Museum of Art, New York]. 


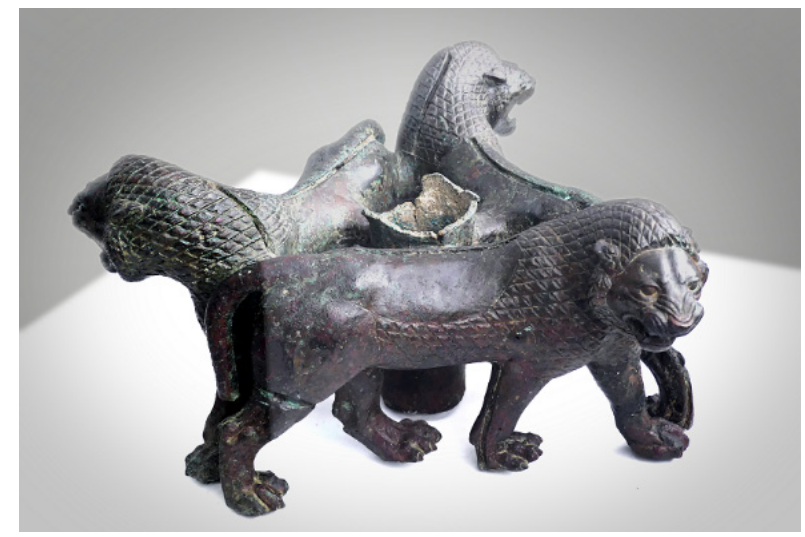

Figure 24. Tripod base with three lion figurines (IMN old inv. no. PT5 642); bronze utensil; Treasury (Hall 38), Persepolis (mod. Iran); Achaemenid, ca. 5th cent. BCE [photography by Linda Tobey, @2018, all rights reserved].

There are some echoes, however, of the staged lion hunting imagery in the Persian palaces, which displays the lion as a dangerous creature. At Persepolis, its presence is recurrent: in several buildings there are images in the Palace of Darius showing a figure fighting beasts, including lions. ${ }^{147}$ For instance, doorways of the main hall and the Throne hall, on both south and north jambs, have a figure fighting and stabbing a lion (Figure 25). ${ }^{148}$ The southern doorway in the west wall of the main hall, on both south and north jambs, has a figure fighting and stabbing a lion-headed monster, while on the northern doorway in the west wall from the main hall there is a corresponding figure fighting a bull, on both south and north jambs. And the southern doorways of small apartments connected with the main hall (room 16 on the east and room 5 on the west) have a figure grasping a lion cub in one hand (arm around its neck and holding its paw) and a dagger in the other hand, about to stab it: preserved intact are two jambs (Figure 26). ${ }^{149}$

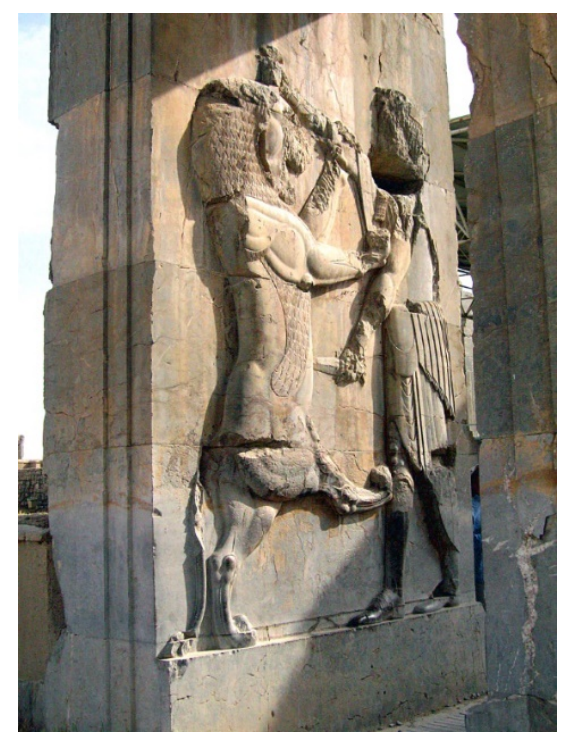

Figure 25. Royal hero fighting and stabbing a lion; south jamb of the southern doorway in the western wall, Throne Hall, Persepolis, Persia (mod. Iran); Achaemenid, ca. 522-465 BCE [photography by Mary Loosemore; used with permission].

147 See (Schmidt 1953, pls. 115-16, 144-45, 146a-b, 147a, d, 195-96; Root 1979, pp. 81-82, 102-3, 107).

148 See (Schmidt 1953, pl. 115a) (south jamb of the southern doorway in the western wall, Throne Hall, Persepolis).

149 See (Schmidt 1953, pl. 147a) (Tachara, Palace of Darius, Persepolis, east jamb of southern doorway of room 16) and pl. 147d (Tachara, Palace of Darius, Persepolis, west jamb of southern doorway of room 5). 


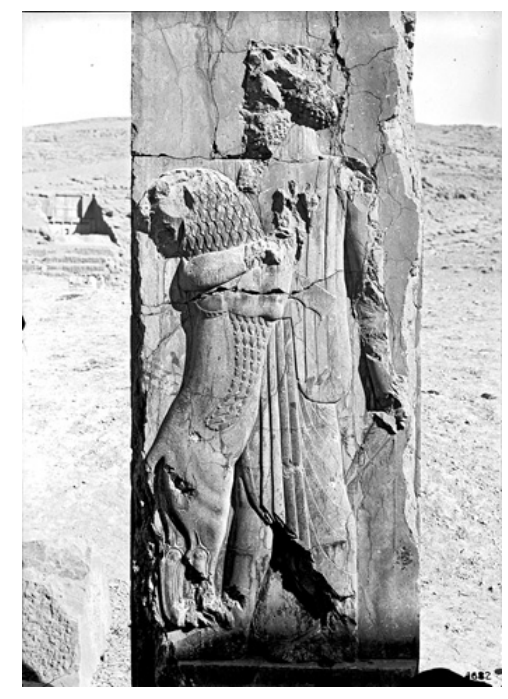

Figure 26. Royal hero strangling a young lion; relief scene; Tachara, Persepolis, Persia (mod. Iran); Achaemenid, ca. 522-465 BCE [photography by Ernst Herzfeld, ca. 1923-1928; image courtesy of the Freer and Sackler Archives, Smithsonian, Washington, D.C., inv. no. A.6 04.GN.1682].

Furthermore, on the doors of Xerxes' so-called "Harem" building, those leading from the west to the main hall have a figure stabbing a lion while holding its forelock on both the south and north jambs, while those leading from the east to the main hall show a figure killing a lion-headed monster while holding its horn.

Similarly, at the entrance to the Throne Hall, the two jambs of the southern doorway in the western wall of the main hall have a figure fighting a lion in the southern doorway, paralleling a figure fighting a bird-headed griffin monster on the jambs of the northern doorway. A comparable set of two jambs of the northern doorway in the eastern wall of the main hall show a figure fighting a lion-headed monster, paralleling a figure fighting a bull on the jambs of the southern doorway in the eastern wall.

The pose of the figure dispatching a lion on the doorways parallels that of the monarch shown on the Assyrian stamp seals (see above) and reliefs. The Achaemenid motif is adapted in that the animals are now mostly fantastic creatures, ${ }^{150}$ and the person is not instantaneously recognized as the monarch, given his strapped shoes and his low headband. ${ }^{151}$ It is presumably some form of the "Persian man", of whom an idealized version was represented by the Great King. ${ }^{152}$ Some impressions of cylinder seals found in the Treasury of Persepolis depict a hero in clash with a lion ${ }^{153}$ or a winged lion (here emphasized as the antagonistic monster). ${ }^{154}$ Mostly, the hero struggles against two lions ${ }^{155}$ or two winged lions. ${ }^{156}$ Incidentally, the imagery of two lions may provide a background for the elements of the story at the beginning of this paper. The image of the hero grasping a lion is ichnographically reminiscent of another hero, the colossal human figure ( $550 \mathrm{~cm}$ in height) from the exterior façade of the throne room of Sargon II (r. 722-705 BCE) in Khorsabad (Figure 27). ${ }^{157}$ It is assumed to represent a hero, probably Gilgamesh. Another similarly colossal (4.5 $\mathrm{m}$ in height) figure (Enkidu?), also holds

150 See (Root 1979, pp. 304-8; Kuhrt 2007, p. 2.546). See (Allen 2005, p. 77) on this transformation into an Achaemenid theme.

151 See (Root 1979, p. 304; Allen 2005, p. 77; Kuhrt 2007, p. 2.546). Yet, see (Wiesehöfer 2001, pp. 24, 220).

152 As persuasively suggested by (Root 1979, pp. 305-7). Cf. DNa 4.43-47: “The Persian man has gone forth far”. See (Barnett 1957, p. 77 n. 2): “[t]he theme of the lion hunt, treated by the Assyrians as a major subject of narrative art, has shrunk at Persepolis to a formal and unconvincing, almost heraldic single combat between the Persian king, typifying good, and a lion, bull or monster, typifying evil" (Seyer 2007). See (Schmidt 1957, p. 32, no. 37, pl. 11, PT 383; p. 37, no. 59, pl. 13, PT6 168). See (Schmidt 1957, p. 37, no. 60, pl. 13, PT4 401) See (Schmidt 1957, pp. 7, 19, no. 3, pl. 3, PT4 860, PT4 331, p. 21, no. 6, pl. 4, PT4 749, PT4 862, p. 22, no. 8, pl. 5, PT4 471, PT4 549a [two heroes against two lions], p. 23, no. 10, pl. 5, PT4 769, no. 12, pl. 5, PT4 979). 
a lion in his left hand and a sword in his right. ${ }^{158}$ The two were placed at the entrance to the palace gate. ${ }^{159}$

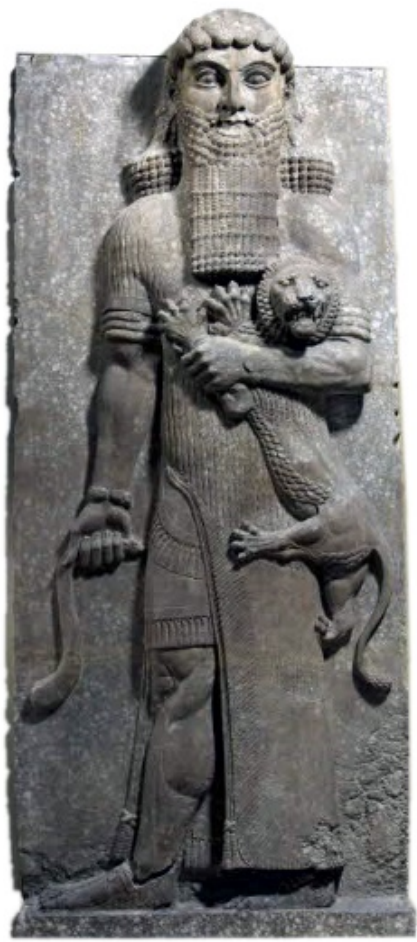

Figure 27. Hero (Gilgamesh?) Overpowering Lion (Louvre inv. no. AO 19862); sculptural relief (partial reconstruction), H. 5.5 m; Palace of Sargon II, present-day Khorsabad (mod. Iraq); NeoAssyrian, ca. 713-705 вСЕ [photography by Thierry Ollivier; courtesy of the Louvre Museum, Paris].

The adaptation of the Neo-Assyrian hunting iconography in a manner which suppresses the instant suggestions of monarchical power, may indicate the significance given to the hunt by the royal and noble families in the Achaemenid period, and how they partially received the Mesopotamian chase of lions as fighting the forces of chaos. One might conclude that the lion hunt was identified with the imperial power of the Assyrians to such an extent that it was forever tainted and branded as repugnant for the elite families in Media, Persia and Elam. The reality was, however, that the lion hunt was practiced by the king and his court. An interesting iconographic display of the ambivalent attitude towards the lion and the hunt is presented in the portrayal of one of the Apadāna delegations and mentioned by Root (2002, pp. 200-1). The Susian (Elamite) delegation (No. II) brings a lioness and two cubs to the monarch, presumably as game to one of his parks (Figure 28). ${ }^{160}$ In contradiction to the other animals brought in the procession (compare the horses above), the lioness is the only one allowed to express emotions, turning her head in anxiety to see her two cubs. This scene captures at once the dual sources of the Achaemenid imperial ideology: the Assyrian imperial one with its emphasis on the royal hunt, and the Elamite and Iranian one, with its attachment to the lion and the awareness of its protective power.

158 Louvre inv. no. AO 19861.

159 See (Cornelius 1989, p. 58; Root 1979, p. 304).

160 See (Schmidt 1953, pl. 28b) (Apadana, Tribute Procession, Eastern Stairway; there is a parallel scene in the northern stairway, but the upper panel is missing). 


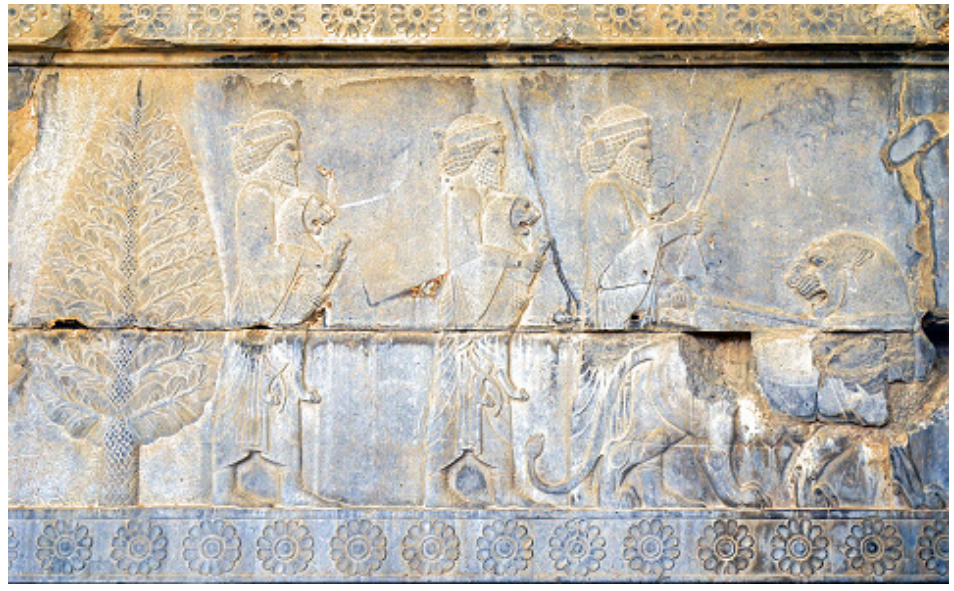

Figure 28. Susian (Elamite) delegation bringing lion and two cups; relief scene; Apadana, Persepolis, Persia (mod. Iran); Achaemenid, ca. 518-486 BCE [image is in the Public Domain; CC-BY-2.0 License].

Furthermore, the reality in other parts of the Persian Empire was also different. First, in the Oxus Treasure from central Asia, there is a fifth- or fourth-century BCE gold sheath probably a votive offering, adorned with engraved scenes of a lion chase, similar to the Assyrian hunting reliefs (Figure 29). ${ }^{161}$ In the upper part, four riders attack lions with spears; in the long narrow part, five horsemen attack lions in a row. Second, in the western parts there are hunting scenes on several royal Achaemenid seals. For instance, the one mentioned above (Figure 5), ${ }^{162}$ in which Darius I is in a chariot, shooting arrows at an attacking lion, and is presented as being helped by a figure in a winged disk, most likely Ahura Mazda. The name of Darius, "the Great King", is marked in a trilingual inscription (Old Persian, Elamite, and Akkadian). ${ }^{163}$ The provenance of the seal is Thebes in Egypt. The seal displays two lions, and this image too might be reminiscent of the passage at the beginning of this paper. Yet, Porada (1965, p. 176) suggests that the seal in fact shows one and the same lion in two stages, namely, facing the king's chariot and then dead under it. Both the narrative type of the monumental reliefs and the convention to show a fallen enemy or victim beneath the horses drawing the victor's chariot are taken from Assyrian art (Figures 2 and 13). ${ }^{164}$

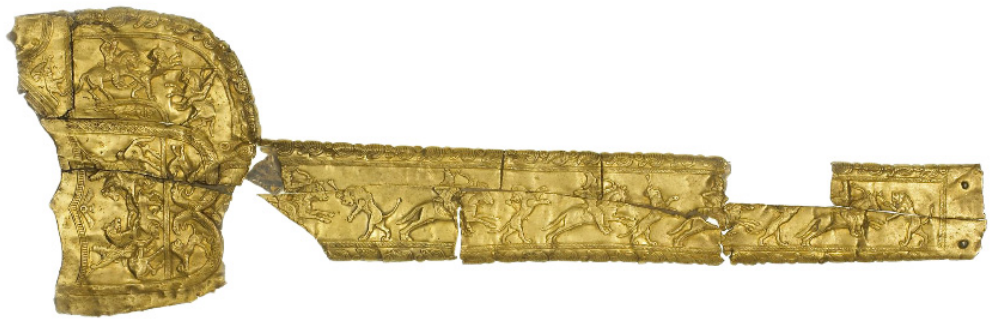

(a)

Figure 29. Cont.

\footnotetext{
161 BM inv. no. 123923 (reg. no. 1897,1231.22); see (Dalton 1964, pp. 9-11, no. 22, pl. 9; Stronach 1998; Curtis and Tallis 2005, p. 233, no. 431).

162 Cf. MMA acc. no. 1984.383.25.

163 See (Collon 1995, pp. 129-30, no. 558; Kuhrt 2007, p. 237).

164 BM inv. nos. 124579 and 124532; see (Curtis and Reade 1995, Nos. 5-6).
} 


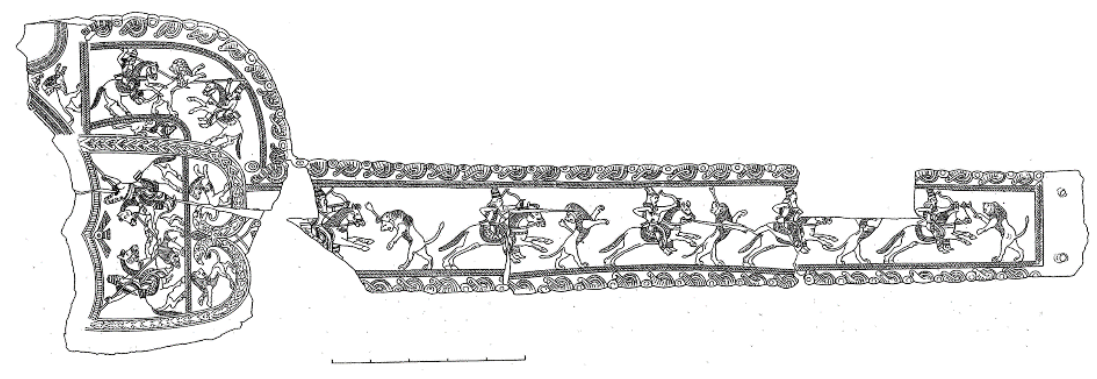

(b)

Figure 29. (a) Ceremonial sheath for scabbard (BM inv. no. 123923; reg. no. 1897,1231.22); armour, gold; found at Takht-i Kuwad (?) (Oxus Treasure), Tajikistan; Achaemenid, ca. 5th cent. BCE (?). [Images courtesy of the Trustees of the British Museum, London]; (b) line drawing of preceding (as above).

In Asia Minor, several fifth- and fourth-century BCE "Greco-Persian" gems show portrayals of Persian aristocratic lion hunts. ${ }^{165}$ Since these gems were made by Greek artisans, ${ }^{166}$ their iconography and its significance were influenced by Greek notions of rivalry and competitiveness among the noble "equals". The hunters are depicted mounted in this Greco-Persian adaptation of the hunting motif. The theme also appears in the Greco-Persian tradition of funerary monuments' hunting friezes, ${ }^{167}$ the most famous of which is a specimen created after Alexander, namely, the so-called Alexander Sarcophagus (found in Sidon, now in the Archaeological Museum, Istanbul), which includes a vignette of a lion attacking a horse (Figure 30$).{ }^{168}$

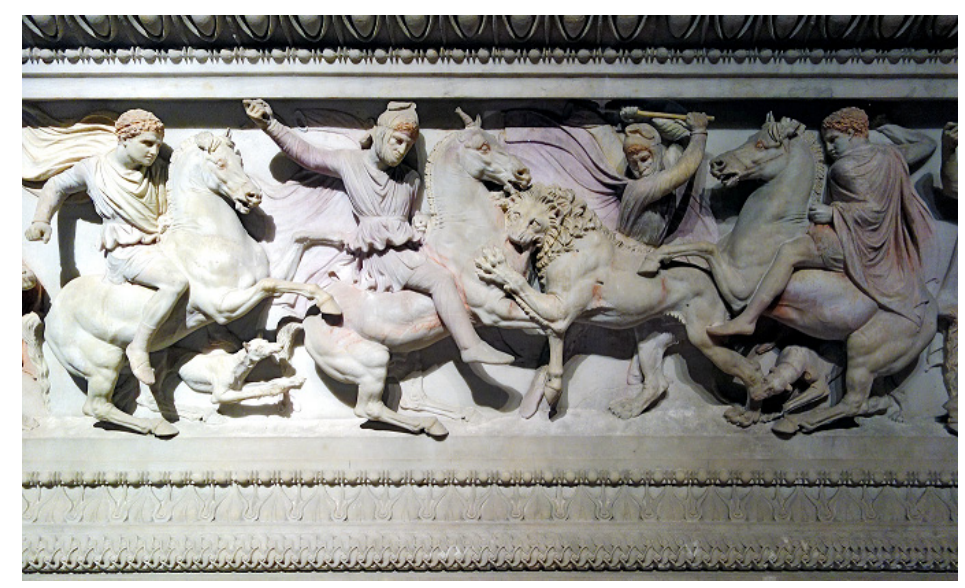

Figure 30. Lion hunt scene on so-called Alexander sarcophagus (IAM inv. no. 72); marble; Sidon, Phoenicia (mod. Lebanon); Hellenistic, ca. 330-310 BCE [photography by Steven Zucker; CC BY-NCSA 2.0 License].

These artefacts and the presence of this iconographic motif testify to the fact that lion hunting in its imperial garb persisted in the reality, if not the ideology displayed in

165 See (Boardman 1970, pp. 314-16, pls. 889, 924, 929). Cf. BM inv. no. 89583 (reg. no. N.1082: cylinder seal; S-E Palace, Nimrud; Achaemenid, ca. 550-330 bce): a rider aims a spear at a rampant lion; BM inv. no. 89816 (reg. no. 1869,0122.10: fragmentary cylinder seal; unknown provenance (Asia); Achaemenid, ca. 5th cent. BCE): a rider turning back in his saddle to aim an arrow (the so-called "Parthian shot").

166 See (Boardman 1970, pp. 304, 323-26).

167 Reliefs of hunting scenes (of a stag and a boar) on one of the long sides of a fourth-century BCE marble sarcophagus have been recently (1998) discovered within a plundered tumulus at Çan, between Ilion and Dascyleum; see (Sevinç et al. 2001).

168 IAM inv. no. 72; see (Anderson 1985, pp. 70, 78-79; Lane-Fox 1996, pp. 138, 142; Barringer 2001, pp. 200-1; Palagia 2000, pp. 167, 175-84, 191-99). The Macedonian lion hunting, however, was probably practiced prior to the conquest of Persia; see (Hull 1964, pp. 101-2; Anderson 1985, p. 80; Briant 1991; Lane-Fox 1996, pp. 137-39, 143). 
monumental sculpture, of the Achaemenid Empire. The hunt was central not only in the royal court but also in the satrapal courts and centers, as described by Xenophon (Cyr. 8.6.10). Moreover, several Greek descriptions also bear witness to the fact that the lion hunt, at least in its representational format, was not suppressed in the western part of the empire. One such depiction is that of a painting of a chase of wild beasts in Semiramis palace in Babylon, in which the queen is mounted throwing a spear at a leopard and Ninus thrusting a lance into a lion at close quarters. ${ }^{169}$ The latter picture resembles the Neo-Assyrian iconography mentioned above. ${ }^{170}$ The portrayal is ultimately taken from the fourth-century BCE Ctesias, who is just mentioned in the preceding passages of Diodorus work. ${ }^{171}$ Ctesias, who stayed for a certain period in the Persian heartland ${ }^{172}$ as a personal physician to the king Artaxerxes II, may have construed the scenes on the doorjambs in Persepolis or on Achaemenid seals in accordance with his prior acquaintance with the hunting imagery in Asia Minor.

The hunt was indeed an important aspect of the real Persian court life, ${ }^{173}$ as can be gleaned again from the Greek texts. It was one of the highest honors given to Themistocles, who resided in the king's court, to participate in the hunt and accompany the monarch. ${ }^{174}$ The author of the work De Mundo (398a), erroneously attributed to Aristotle, shows the great significance that nobles attached to the hunt in arranging and taking responsibility for some of its features, ${ }^{175}$ like being "leaders of war and hunting" ( $\sigma \tau \rho \alpha \tau \eta \gamma o \grave{~} \pi \mathrm{o} \lambda \varepsilon \dot{\mu} \mu \omega v$ $\kappa \alpha i \kappa v \vee \eta \gamma \varepsilon \sigma i(\omega v)$. The fact that Alexander and his entourage preserved the practice of hunting lions and other animals as well as the symbolism and honor ascribed to it, show that it continued unhindered during the Achaemenid period. ${ }^{176}$

Hunting in Achaemenid Persia therefore became a court activity, echoing the previous importance assigned to it as part of the nomadic lifestyle. On the other hand, it reflected the complete transformation of this practice into an artificial and controlled pastime, whose importance lay in the system of honors it apportioned to members of the political and social elite, and which had political implications in its royal/central or satrapal/local settings. ${ }^{177}$ To see how much the royal hunt of the sedentary Persians was different from the aristocratic nomadic hunt one need only recall the special protocol used in the royal hunts, which asserted it was the monarch's privilege to throw the first lance at the beast. ${ }^{178}$ According to the tale of Megabyzus, as told by Ctesias ( $F G r H 688$ F 14.43), this Persian courtier, while hunting with Artaxerxes I, hit a charging lion with his spear. The story is similar to one at the beginning of this paper, except for the fact that the Great King was enraged at Megabyzus for the apparent slight, since the flouting of court code has impaired the Achaemenid royal ideological association between hunting, courage and rightfulness of the claim to the throne. It is no wonder that Artaxerxes I's response was to command to execute Megabyzus.

Due to this meticulous attention to protocol details, the contrary Persian attempt to underplay the importance of the hunt in monumental sculpture was presumably noticed by the Greeks. A supposed absence of this practice was perceived as indicative of the monarchy's weakness. The ending of Xenophon's Cyropaedia, for instance, although overly rhetorical, highlights the discrepancy between the current decadent state of the Persians and their former rougher condition. The author flags the avoidance of hunting as one of the signs demonstrating the corruption and decay of the Persian Empire:

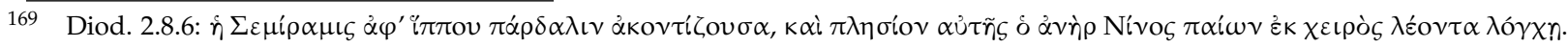

170 See (Briant 2002, p. 207).

171 Diod. 2.7.1, 3-4, 2.8.5. It is set by Jacoby as part of his lengthy FGrH $688 \mathrm{~F} 1 \mathrm{~b}$

172 He was certainly in Babylonia: as Parysatis' physician (FGrH 688 F 27.69), he most probably accompanied her during her sojourn there (Plut. Art. 19.10); cf. the constant allusions to Babylon in his Indica: F 45b $\alpha$, 45.29. See (Almagor 2012, pp. 19-20).

173 See (Briant 2002, p. 297).

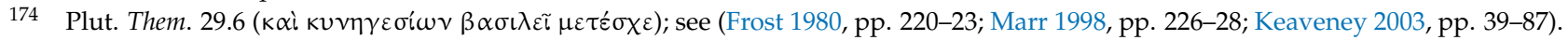

175 See (Llewellyn-Jones 2013, p. 131).

176 The Macedonians king boasts to have allegedly killed a large number of beasts, following the Mesopotamian practice noted above: (Curt. Ruf. 8.1.19: 4000); cf. Lysimachus who hunted a huge lion (ib. 8.1.15, cf. Justin, 15.3.7-8), and Perdiccas who captured lion cubs (Ael. VH 12.39).

177 See (Llewellyn-Jones 2013, p. 130).

178 See Xen. Cyr. 1.4.14. 
In times past, they used to go out hunting so often that the hunts afforded sufficient exercise for both men and horses. However, since Artaxerxes and his court became the victims of wine, they have neither gone out themselves in the old way nor taken the others out hunting. ${ }^{179}$

\section{An Afterthought and Conclusions: The Horse, the Lion, and the Persians' Two Modes of Life}

At the end of his work, Herodotus takes the readers back to Cyrus the Great. Just after subduing the Medes and before the Persians were to create a great empire, a proposal is made to the Persian leader to change their small and rugged land with a better one. Cyrus gives this famous retort:

Soft lands breed soft men; wondrous fruits of the earth and valiant warriors grow not from the same soil. ${ }^{180}$

The Persians are so convinced of the truth of this statement that they choose to remain in their poor land and be rulers rather than "sow crops in a level plain and be slaves to others" (the very last words of the work). This depiction is of course unrealistic, since we know that the Persians actually expanded further than their own rugged land. In fact, the passage contradicts the picture at the beginning of the work, where Cyrus orders his men to clear a region for cultivation one day and on the next day entertains them with wine and a feast. When he asks them what they like better, the Persians opt for the second day's experience. In which case Cyrus exclaims:

This is your case, men of Persia: obey me and you shall have these good things and ten thousand others besides with no toil and slavery; but if you will not obey me, you will have labours unnumbered, like the toil of yesterday. Now, therefore, do as I bid you, and win your freedom [ ... ] All this is true; wherefore now revolt from Astyages with all speed. ${ }^{181}$

After this, the Persians are convinced and begin their campaign for liberation from the Medes, which would end in the establishment of their Empire. There cannot be, therefore, any greater variance than these two passages. ${ }^{182}$ The last section of the work may seem to lead the readers into some sort of a "virtual history" type of recounting the events of the past. That is to say, "what would have happened if"-if only the Persians had stayed in their own land and not attacked the wealthier countries. They probably would not have been endangered by the Greeks. Yet, when the starting point of the work, with the clash of Persians and Greeks and its causes, is read through the ending, it leads the readers to understand that the Persians did conquer more fertile countries and eventually became soft themselves. The presence of the two sections in the work is tantamount to characterizing the Persians in two modes of life, the soft and the rough, as if co-existing. ${ }^{183}$

These two depictions are actually variant stereotypes that the Greeks attributed to their celebrated eastern neighbors. Two types of behavior, that is, boldness and softness, are employed by Classical authors to typify the Persians. While the Persians are presented

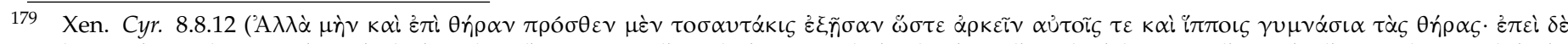

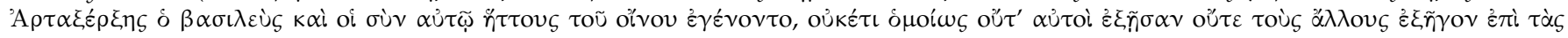
$\theta \dot{n} \rho \alpha \varsigma$ ), trans. adapted from Miller (LCL series).

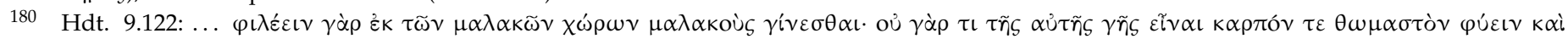

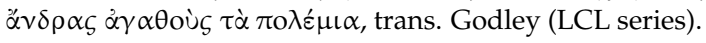

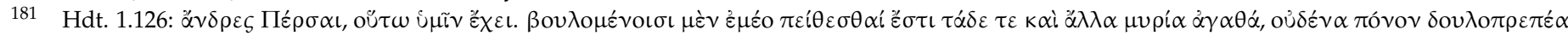

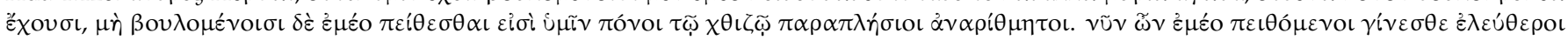

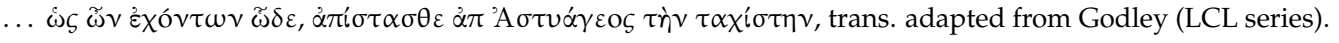

183 Another manner in which Herodotus recounts the unnatural progression of the Persians from one mode of life to another is through the fantastic portent just at the moment Xerxes' army was about to cross into Europe: a horse gives birth to a hare (7.57). While playing with the notion of hybridity, which symbolizes Cyrus the Great and the Persians (see above), Herodotus also commented this way on the metamorphosis of the Persians into restless imperialists moving from one place to another (cf. the use of a hare to denote the similar transition of the Spartans towards imperialism in Plut. Cim. 16.5). 
as submissive slaves, at the same time they may be viewed as uninhibited-specifically their master, the Great King. Thus, on the one hand there is an absence of freedom visible in Persia, on the other hand, an absence of law.

It is intriguing that the Persians themselves maintained some sort of dichotomy in their sense of identity or in their official self-presentation. The split is between what was displayed as the "Mede" and the "Persian"-found in the expression "Persia and Media" in official accounts, ${ }^{184}$ and in the reliefs in Persepolis, which portray alternating Mede and Persian figures. ${ }^{185}$ The Mede is typically dressed in the so-called hunting or riding costume ${ }^{186}$ while the Persian displays the typical court garb. ${ }^{187}$ These are the two sides of the same imperial portrait. The riding costume apparently belongs to the pre-imperial, nomadic, Persian mode of subsistence (roughly corresponding to what the Greeks saw as "hard" life) ${ }^{188}$ and the Persian clothing to the sedentary-imperial being (what the Greeks termed 'soft' life). It is quite the reverse of what the Greek authors associate with "Median" and "Persian" existence, namely, that the Medes were overly civilized decadent people as opposed to the rugged Persians. ${ }^{189}$ Yet, it is fascinating that the Greeks were accurate in depicting a dichotomy, which the Achaemenid royalty and nobility did maintain in order to preserve aspects that went back to their nomadic way of life.

In this paper, I have tried to show how these two sides of the Persians, perceived as "hard" and "soft" by the Greeks—or rough and decadent-were observable in a twofold attitude towards two significant animals, that is, the horse and the lion. The significance of these two beasts is both symbolic and practical, and has everything to do with that split or dichotomy. I hope to have shown that certain attitudes visible during the Achaemenid Persian period reflected the significant transition in their history, namely from nomadic to sedentary people, and from the margins of the Neo-Assyrian empire to the center of power. I have presented a certain transformation in the meaning of these animals, resulting in a combination of imperial and pre-imperial approaches with regard to the horse and lion. As nomads, the Persians attached great importance to horses in a social context-in which horsemanship was valued and provided a means of legitimacy for the king-in education, as a source of pride and prestige, and in religious rites, where it was sacrificed in honor of the sun. In the Persian sedentary society of the Empire, the horse assumed a different meaning as a symbol of the central power as well as of the means to expand the scale of civilization, for example in the famous postal system. In the case of the lion, the paper displayed a varied attitude, between suppression and continuation of the hunt, which also divided between east and west. As successors of the Neo-Assyrian Empire, the Persians continued the practice of imperial lion hunting with its symbolic meaning of overcoming the power of dangerous chaos. Yet, in the eastern monumental representations the hunt is absent, because of ideological reasons going back to the religious significance the lion

184 See the expression Pârsa utâ Mâda (DB 1.41, 1.46-47, 2.18, 2.81-82, 3.29-30, 3.77). Cf. Esther 1:3, 14, 1:13, cf. 10:2, Medes and Persians: Daniel 5:23, 6:8, 12, 15, 8:20. See, however (Stronach 2009, p. 222).

185 Persons in alternate Persian and Median clothing in the Persepolis reliefs: see (Schmidt 1953, pp. 83-84, 107, 141, 225, 228, 240, 243, 280, pls. 22, 53, 64-65, 85-86, 96-101, 134-35, 161, 163-65, 185c-d, 203a, 204a, 205; Roaf 1983, pp. 29-30, 41, 83, 85, 103-14, 124, 140-41, 145, 149; Root 1979, p. 282).

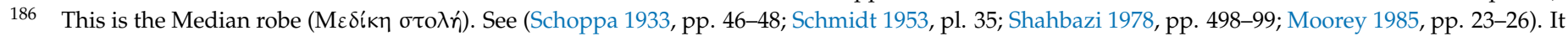
was an upper garment/ coat with long, false sleeves, called Kandys; see (Widengren 1956, pp. 235, 237-38). A purple robe: cf. Xen. Cyr. 8.3.10; Pollux 7.58; possibly Strabo, 15.3.19; cf. Hdt. 3.20, 9.109 with (Thompson 1965, p. 122). Trousers were also part of the "Median" costume (cf. Hdt. 1.71, 7.64; Xen. Anab. 1.5.8), as well as a belted skirt.

187 This is the royal or Persian robe (presumably from an Elamite origin), the two-piece red or purple loose pleated garment. See (Schoppa 1933, p. 47;

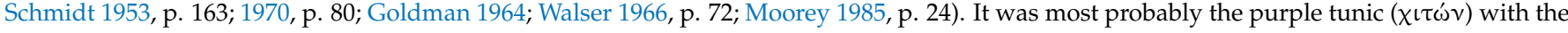
white middle ( $\mu \varepsilon \sigma o ́ \lambda \varepsilon \cup$ ко $)$ ): cf. Hdt. 7.61; Xen. Anab. 1.5.8, Cyr. 1.3.2, 8.3.13 (together with Median articles of clothing); Ephippus ap. Ath. 12.537e [Alexander]; called Sarapis in Elamite and Persian: Hesychius, s.v. "Sarapis", Photius, Lexicon, s.v. "Sarapis". Cf. Plut. Alex. 51.5 with (Collins 2012, pp. 387-90). See also Diod. 17.77.5-6, Curt. Ruf. 3.3.17. Cf. Duris ap. Ath, 12.535e [Pausanias]. Ancient authors appear to confuse the Median and the Persian robes, erroneously deeming the former as more luxurious and the latter simpler: cf. Hdt. 1.71, 1.135; Xen. Cyr. 2.4.5, 8.1.40-41, 8.3.3, influencing the Alexander historians (cf. Plut. Alex. 45.2, De Fort. Alex. Magn. 329f-330a). Some modern scholars also conflate the two: cf. Schmidt 1953, p. 168 n. 38. Others believe that there was indeed a transition from an Elamite/Persian dress to a Median one in the early fifth century BCE: see (Sekunda 2010, pp. 255-64).

188 See (Thompson 1965, p. 123): "while the [Median dress] was well adapted to the way of life pursued by nomad warriors and hunters, the Persian robe did not share this advantage, being full and voluminous".

189 Hdt. 1.135, 6.112; Ctesias (FGrH 688 F 1b.2.23.1-4: the Median effeminate decadence of Sardanapalus); Xen. Cyr. 8.8.15; Strabo 11.13.9. 
had for pre-imperial Persians; this importance is rather observable in the numerous other manifestations of the lion in monumental Persian art. The symbolism of these two beasts can be applied onto the Persians themselves. Thus, it can be seen that the latter attempted to preserve both their leonine side, as it were-related to the wild, non-imperial reality, in which the lion had a significant protective power-and their equine aspects, which had to do with both the soft, domesticated, civilized and luxurious life as well as the hard, nomadic mode of existence.

Funding: This research received no external funding.

Acknowledgments: I would like to thank Branko van Oppen for his assistance during the production of this paper. I would also like to thank Sian Lewis and Lloyd Llewellyn-Jones for organizing the conference panel in which a preliminary form of this paper was delivered. I would also like to thank Mark Garrison (Trinity University, San Antonio, TX, USA) for the image used for Figure 1.

Conflicts of Interest: The author declares no conflict of interest.

$\begin{array}{ll}\text { Abbreviations } \\ \text { BM } & \text { The British Museum, London } \\ \text { EHAM } & \text { Erebuni Historical and Archaeological Museum-Reserve, Yerevan } \\ \text { IAM } & \text { Istanbul Archaeology Museums (İstanbul Arkeoloji Müzeleri) } \\ \text { INM } & \text { Iran National Museum (Mūze-ye Irān-e Bāstān), Tehran } \\ \text { IrMus } & \text { Iraq Museum, Bagdad } \\ \text { JPGM } & \text { J. Paul Getty Museum and Villa, Los Angeles } \\ \text { Louvre } & \text { Musée du Louvre, Paris } \\ \text { MMA } & \text { The Metropolitan Museum of Art, New York } \\ \text { OIM } & \text { Oriental Institute Museum, Chicago } \\ \text { PFS } & \text { Persepolis Fortification Sealings }\end{array}$

\section{References}

Aalto, Pentti. 1975. The Horse in Central Asian Nomadic Cultures. Studia Orientalia 46: 1-10.

Afshar, Ahmad, and Judith Lerner. 1979. The Horses of the Ancient Persian Empire at Persepolis. Antiquity 53: 44-47.

Albenda, Pauline. 1972. Ashurnasirpal II Lion Hunt Relief BM 124534. Journal of Near Eastern Studies 31: 167-78. [CrossRef]

Albenda, Pauline. 1974. Lions on Assyrian wall reliefs. Journal of the Ancient Near Eastern Society 6: 1-27.

Alizadeh, Abbas. 2008. Prehistoric Mobile Pastoralism in Southwestern Iran. In Nomads, Tribes, and State in the Ancient Near East. Edited by Jeffrey Szuchman. Chicago: Chicago University Press, pp. 129-46.

Allen, Lindsay. 2005. The Persian Empire: A History. London: The British Museum Press.

Allen, Lindsay, John Ma, Christopher J. Tuplin, and David G. K. Taylor. 2014. The Arshama Letters from the Bodleian Library, Volume 2 Part 1: Edition of the Egyptian Aramaic Documents in the Bodleian Library. Available online: http://blogs.bodleian.ox.ac.uk/ wp-content/uploads/sites/116/2013/10/Vol-2-intro-25.1.14.pdf (accessed on 9 May 2021).

Almagor, Eran. 2012. Ctesias and the Importance of his Writings Revisited. Electrum 19: 9-40.

Almagor, Eran. 2014. Hold Your Horses: Characterization through Animals in Plutarch's Artaxerxes, Part II. Ploutarchos 11: 3-18. [CrossRef]

Almagor, Eran. 2018. Plutarch and the Persica. Edinburgh: Edinburgh University Press.

Almagor, Eran. 2021. The Royal Road from Herodotus to Xenophon (Via Ctesias). In Aršāma and His World: The Bodleian Letters in Context. Edited by Christopher J. Tuplin and John Ma. Oxford: Oxford University Press, pp. 147-85.

Almagor, Eran. forthcoming. Hunting and Leisure Activities. In A Companion to the Achaemenid Persian Empire. Edited by Bruno Jacobs and Robert Rollinger. Malden: Wiley-Blackwell.

Amiet, Pierre. 1966. Elam. Auvers-sur-Oise: Archee.

Anderson, John Kinlich. 1985. Hunting in the Ancient World. Berkeley: University of California Press.

André-Salvini, Béatrice. 1992. The Monuments of Puzur-Inshushinak. In The Royal City of Susa: Ancient Near Eastern Treasures in the Louvre. Edited by Prudence Oliver Harper, Joan Aruz and Françoise Tallon. New York: The Metropolitan Museum of Art, pp. 87-91.

Anthony, David. W., and Dorcas R. Brown. 2000. Eneolithic Horse Exploitation in the Eurasian Steppes: Diet, Ritual and Riding. Antiquity 74: 75-86. [CrossRef]

Anthony, David W., Dimitri Y. Telegin, and Dorcas R. Brown. 1991. The Origin of Horseback Riding. Scientific American 265: 94-100. [CrossRef]

Archie, Andre. 2015. Politics in Socrates' Alcibiades: A Philosophical Account of Plato's Dialogue Alcibiades Major. New York: Springer. 
Asheri, David, Alan Brian Lloyd, and Aldo Corcella, eds. 2007. A Commentary on Herodotus: Books I-IV. Oxford: Oxford University Press.

Barnett, Richard D. 1957. Persepolis. Iraq 19: 55-77. [CrossRef]

Barnett, Richard D. 1976. Sculptures from the North Palace of Ashurbanipal at Nineveh (668-627 B.C.). London: British Museum.

Barringer, Judith M. 2001. The Hunt in Ancient Greece. Baltimore: Johns Hopkins University Press.

Benveniste, Émile. 1932. Les classes sociales dans la tradition avestique. Journal Asiatique 221: 117-34.

Beyer, Dominique. 1990. Le palais de Sargon II, roi d'Assyrie. Le Monde de la Bible 67: 19-21.

Boardman, John. 1970. Greek Gems and Finger Rings: Early Bronze Age to Late Classical. London: Thames and Hudson.

Boardman, John. 2000. Persia and the West. An Archaeological Investigation of the Genesis of Achaemenid Art. London: Thames and Hudson.

Boardman, John. 2006. The Oxus Scabbard. Iran 44: 115-19. [CrossRef]

Boyce, Mary. 1975. A History of Zoroastrianism. Leiden: Brill, vol. 1.

Briant, Pierre. 1991. Chasses royales macédoniennes et chasses royales perses: Le thème la chasse au lion sur la chasse de Vergina. DHA 17: 211-55. [CrossRef]

Briant, Pierre. 2002. From Cyrus to Alexander. Winona Lake: Eisenbrauns.

Cahill, Nicholas. 1985. The Treasury at Persepolis: Gift-Giving at the City of the Persians. American Journal of Archaeology 89: 373-89. [CrossRef]

Collins, Paul. 2009. Assyrian Palace Sculptures. Austin: University of Texas Press.

Collins, Andrew W. 2012. The Royal Costume and Insignia of Alexander the Great. American Journal of Philology 133: 371-402. [CrossRef]

Collon, Dominique. 1995. Ancient Near Eastern Art. Berkeley: University of California Press.

Cornelius, Izak. 1989. The Lion in the Art of the Ancient Near East: A Study of Selected Motifs. Journal of Northwest Semitic Languages 15: 53-85.

Cremer, Marielouise. 1984. Zwei neue graeco-persische Stelen. Epigraphica Anatolica 3: 87-99.

Curtis, John E., and Julian E. Reade, eds. 1995. Art and Empire: Treasures from Assyria in the British Museum. Exhibition Catalogue. New York: The Metropolitan Museum of Art.

Curtis, John E., and Nigel Tallis, eds. 2005. Forgotten Empire: The World of Ancient Persia. London: The British Museum Press.

Dalton, Ormonde Maddock. 1964. Treasure of the Oxus with Other Examples of Early Oriental Metal-Work, 3rd ed. London: The British Museum Press.

Denyer, Nicholas. 2001. Plato: Alcibiades. Cambridge: Cambridge University Press.

Downs, James F. 1961. The Origin and Spread of Riding in the Near East and Central Asia. American Anthropologist 63: 1193-203. [CrossRef]

Drews, Robert. 2004. Early Riders. The Beginnings of Mounted Warfare in Asia and Europe. London: Routledge.

Driver, Godfrey R. 1965. Aramaic Documents of the Fifth Century B.C. Oxford: Clarendon Press.

Durand, Jean-Marie. 1998. Documents Epistolaires du Palais de Mari. Paris: Cerf, vol. 2.

Dyson, Robert H., Jr. 1961. Excavating the Mannaean Citadel of Hasanlu; and New Light on Several Millennia of Persian Azerbaijan. Illustrated London News 239: 534-37.

Farkas, Ann. 1974. The Horse and Rider in Achaemenid Art. Persica 4: 57-76.

Frankfort, Henri. 1939. Cylinder Seals. London: Macmillan.

Frankfort, Henri. 1954. The Art and Architecture of the Ancient Orient. London: Penguin Books.

Frost, Frank J. 1980. Plutarch's Themistocles: A Historical Commentary. Princeton: Princeton University Press.

Frye, Richard Nelson. 1984. The History of Ancient Iran. Munich: Beck.

Gabrielli, Marcel. 2006. Le Cheval dans l’Empire Achéménide. Istanbul: Ege Yayinlari.

Garrison, Mark B. 2011. The Seal of "Kuras the Anzanite, Son of Sespes" (Teispes), PFS 93*: Susa-Ansan-Persepolis. In Elam and Persia. Edited by Javier Álvarez-Mon and Mark B. Garrison. Winona Lake: Eisenbrauns, pp. 375-405.

Garrison, Mark B., and Margaret Cool Root. 1996. Persepolis Seal Studies. An Introduction with Provisional Concordances of Seal Numbers and Associated Documents on Fortification Tablets 1-2087. Leiden: Brill.

Gershevitch, Ilya. 1959. The Avestan Hymn to Mithra. Cambridge: Cambridge University Press.

Gheorghiu, Dragoş. 1993. A First Representation of a Domesticated Horse in the 5th Millennium B.C. in Eastern Europe? Ceramic Evidence. In The History of the Knowledge of Animal Behavior. Edited by Liliane Bodson. Liège: Université de Liège, pp. 95-115.

Ghirshman, Roman. 1954. Iran from the Earliest Times to the Islamic Conquest. Harmondsworth: Penguin Books.

Gnoli, Gherardo. 1979. Sol Persice Mithra. In Mysteria Mithrae. Edited by Ugo Bianchi. Leiden: Brill, pp. 725-40.

Goldman, Bernard. 1964. Origin of the Persian Robe. Iranica Antiqua 4: 133-52.

Graf, David F. 1994. The Persian Royal Road System. Achaemenid History 8: 167-89.

Grayson, Albert Kirk. 1991. Assyrian Rulers of the Early First Millennium BC, I: 1114-859 BC, Royal Inscriptions of Mesopotamia., Assyrian Periods, 2. Toronto: University of Toronto Press.

Gribble, David. 1999. Alcibiades and Athens: A Study in Literary Presentation. Oxford: Clarendon Press.

Hall, Edith. 1989. Inventing the Barbarian. Oxford: Clarendon Press.

Hanslik, Rudolf. 1936. Nisaîon pedíon. Realencyclopädie der classischen Altertumswissenschaft 17: 712-13.

Hansman, John. 1972. Elamites, Achaemenians and Anshan. Iran 10: 101-24. [CrossRef]

Hartner, Willy. 1965. The Earliest History of the Constellations in the Near East and the Motif of the Lion-Bull Combat. Journal of Near Eastern Studies 24: 1-16. [CrossRef] 
Hartner, Willy, and Richard Ettinghausen. 1964. The Conquering Lion, the Life Cycle of a Symbol. Oriens 17: 161-71. [CrossRef] Herzfeld, Ernst. 1929. Bericht über die Ausgrabungen von Pasargadae, 1928. Archäologische Mitteilungen aus Iran 1: 4-16.

Herzfeld, Ernst. 1941. Iran in the Ancient East. New York and London: Oxford University Press.

Herzfeld, Ernst. 1968. The Persian Empire: Studies in Geography and Ethnography of the Ancient Near East. Wiesbaden: Steiner.

Hull, Denison Bingham. 1964. Hounds and Hunting in Ancient Greece. Chicago: University of Chicago Press.

Justi, Ferdinand. 1895. Iranisches Namenbuch. Marburg: Olms.

Kahn, Dan'el. 2008. Inaros' rebellion against Artaxerxes I and the Athenian Disaster in Egypt. Claasical Quarterly 58: 424-40. [CrossRef]

Kawami, Trudy S. 1986. Greek Art and Persian Taste: Some Animal Sculptures from Persepolis. American Journal of Archaeology 90: 259-67. [CrossRef]

Keaveney, Arthur. 2003. The Life and Journey of Athenian Statesman Themistocles (524-460 B.C.?) as a Refugee in Persia. Lewiston, Queenston and Lampeter: Edwin Mellen Press.

Kelekna, Pita. 2009. The Horse in Human History. Cambridge: Cambridge University Press.

Kellens, Jean. 1974. Les Noms-Racines de l'Avesta. Wiesbaden: Dr. Ludwig Reichert Verlag.

Kinnier-Wilson, James V. 1972. The Nimrud Wine Lists, A Study of Men and Administration at the Assyrian Capital in the Eighth Century B.C. London: British School of Archaeology in Iraq.

Kuhrt, Amélie. 2007. The Persian Empire: A Corpus of Sources from the Achaemenid Period. London: Routledge, vol. 2.

Lane-Fox, Robin. 1996. Ancient Hunting: From Homer to Polybius. In Human Landscapes in Classical Antiquity. Edited by Graham Shipley and John Salmon. London: Routledge, pp. 119-53.

Levine, Marsha. 1999. The Origins of Horse Husbandry on the Eurasian Steppe. In Late Prehistoric Exploitation of the Eurasian Steppe. Edited by Marsha Levine, Yuri Rassamakin, Aleksandr Kislenko and Nataliya Tatarintseva. Cambridge: McDonald Institute for Archaeological Research, pp. 5-58.

Linder, Rudi Paul. 1981. Nomadism, Horses and Huns. Past and Present 92: 3-19. [CrossRef]

Littauer, Mary Aiken, and Joost H. Crouwel. 1979. Wheeled Vehicles and Ridden Animals in the Ancient Near East. Leiden: Brill.

Llewellyn-Jones, Lloyd. 2013. King and Court in Ancient Persia. Edinburgh: Edinburgh University Press.

Luckenbill, Daniel David. 1926. Ancient Records of Assyria and Babylonia. Chicago: Chicago University Press, vol. 1.

Marcus, Michelle I. 1994. Dressed to Kill: Women and Pins in Early Iran. Oxford Art Journal 17: 3-15. [CrossRef]

Marr, John L. 1998. Plutarch: Life of Themistocles. Warminster: Aris \& Phillips.

Mayrhofer, Manfred. 1977. Zum Namengut des Avesta. Vienna: Verlag der Österreichischen Akademie der Wissenschaften.

Mitchell, Terence C. 2000. The Persepolis Sculptures in the British Museum. Iran 38: 49-56. [CrossRef]

Moorey, Peter Roger Stuart. 1985. The Iranian Contribution to Achaemenid Material Culture. Iran 23: 21-37. [CrossRef]

Mossman, Judith M. 2010. A Life Unparalleled: Plutarch's Artaxerxes. In Plutarch's Lives: Parallelism and Purpose. Edited by Noreen Humble. Swansea: CPW, pp. 145-68.

Muscarella, Oscar White. 1980. Excavated and Unexcavated Achaemenian Art. In Ancient Persia: The Art of an Empire. Edited by Denise Schmandt-Besserat. Malibu: Undena, pp. 23-42.

Muscarella, Oscar White. 1988. Bronze and Iron: Ancient Near Eastern Artifacts in the Metropolitan Museum of Art. New York: The Metropolitan Museum of Art.

Muscarella, Oscar White. 2004. The Hasanlu Lion Pins Again. In A View from the Highlands: Archaeological Studies in Honour of Charles Burney. Edited by Antonio Sagona. Leuven: Peeters, pp. 693-710.

Palagia, Olga. 2000. Hephaestion's Pyre and the Royal Hunt of Alexander. In Alexander the Great in Fact and Fiction. Edited by Albert Brian Bosworth and Elizabeth J. Baynham. Oxford: Oxford University Press, pp. 167-206.

Pelling, Christopher Brendan Reginald. 2019. Herodotus and the Question Why. Austin: University of Texas Press.

Porada, Edith. 1965. The Art of Ancient Iran: Pre-Islamic Cultures, rev. ed. New York: Greystone Press.

Potts, Daniel T. 2005. Cyrus the Great and the Kingdom of Anshan. In Birth of the Persian Empire. Edited by Vesta Sarkhosh Curtis and Sarah Stewart. London: I. B. Tauris in association with The London Middle East Institute at SOAS and The British Museum, vol. 1, pp. 1-27.

Potts, Daniel T. 2014. Nomadism in Iran: From Antiquity to the Modern Era. Oxford: Oxford University Press.

Pritchard, James B. 1969. Ancient Near Eastern Texts Relating to the Old Testament, 3rd ed. Princeton: Princeton University Press.

Radner, Karen. 2003. An Assyrian View on the Medes. In Continuity of Empire (?): Assyria, Media, Persia. Edited by Giovanni B. Lanfranchi, Michael Roaf and Robert Rollinger. Padova: Sargon Editrice e Libreria, pp. 37-64.

Razmjou, Shahrokh. 2018. Propaganda and Symbolism: Representations of the Elamites at the Time of Ashurbanipal. In The Elamite World. Edited by Javier Álvarez-Mon, Gian Pietro Basello and Yasmina Wicks. London: Routledge, pp. 340-60.

Reade, Julian E. 1998. Assyrian Sculpture, 2nd ed. London: The British Museum Press.

Roaf, Michael. 1983. Sculptures and Sculptors at Persepolis. Iran 21: 1-164. [CrossRef]

Roaf, Michael. 1995. Media and Mesopotamia: History and Architecture. In Later Mesopotamia and Iran: Tribes and Empires, 1600-539 BC: Proceedings of a Seminar in Memory of Vladimir G. Lukonin. Edited by John E. Curtis. London: The British Museum Press, pp. 54-66.

Root, Margaret Cool. 1979. The King and Kingship in Achaemenid Art. Leiden: Brill.

Root, Margaret Cool. 2002. Animals in the Art of Ancient Iran. In A History of the Animal World in the Ancient Near East. Edited by Billie Jean Collins. Leiden: Brill, pp. 169-209.

Sachs, Abraham J. 1953. The Late Assyrian Royal-Seal Type. Iraq 15: 167-70. [CrossRef] 
Schleiermacher, Friedrich Daniel Ernst. 1836. Introductions to the Dialogues of Plato. Translated by William Dobson. Cambridge: Pitt Press.

Schmidt, Erich F. 1953. Persepolis I: Structures, Reliefs, Inscriptions. Chicago: Chicago University Press.

Schmidt, Erich F. 1957. Persepolis II: Contents of the Treasury and Other Discoveries. Chicago: Chicago University Press.

Schmidt, Erich F. 1970. Persepolis III: The Royal Tombs and Other Monuments. Chicago: Chicago University Press.

Schmitt, Rüdiger. 1988. Achaimenideninschriften in griechischer literarischer Überlieferung. In A Green Leaf: Festschrift for J.P. Asmussen (=Acta Iranica 28). Edited by Jacques Duchesne-Guillemin, Werner Sundermann and Fereydun Vahman. Leiden: Brill, pp. 17-38.

Schoppa, Helmut. 1933. Die Darstellung der Perser in der Griechischen Kunst bis zum Beginn des Hellenismus. Coburg: Tageblatt-Haus.

Seidl, Ursula. 1989. Die Babylonischen Kudurru-Reliefs. Fribourg and Göttingen: Universitätsverlag Freiburg Schweiz/Vandenhoeck \& Ruprecht.

Sekunda, Nicholas Victor. 2010. Changes in Achaemenid Royal Dress. In The World of Achaemenid Persia. History, Art and Society in Iran and the Ancient Near East. Edited by John E. Curtis and St John Simpson. London: I. B. Tauris, pp. 255-72.

Sevinç, Nurten, Körpe Reyhan, Tombul Musa, Rose Charles Brian, Strahan Donna, Kiesewette Henrike, and Wallrodt John. 2001. A New Painted Graeco-Persian Sarcophagus from Çan. Studia Troica 11: 383-420.

Seyer, Martin. 2007. Der Herrscher als Jäger. Untersuchungen zur Königlichen Jagd im Persischen und Makedonischen Reich vom 6.-4. Jahrhundert v. Chr. Sowie unter den Diadochen Alexanders des Großen. Vienna: Phoibos.

Shahbazi, Alireza Shapour. 1978. New Aspects of Persepolitan Studies. Gymnasium 85: 487-500.

Shorey, Paul. 1933. What Plato Said. Chicago: University of Chicago Press.

Simpson, St John, Michael R. Cowell, and Susan La Niece. 2010. Achaemenid Silver, T.L. Jacks and the Mazanderan Connection. In The World of Achaemenid Persia, Proceedings of a Conference at the British Museum, September 29-October 1. Edited by John E. Curtis and St John Simpson. London and New York: I. B. Tauris, pp. 429-44.

Smith, Nicholas D. 2004. Did Plato Write the "Alcibiades I?". Apeiron 37: 93-108. [CrossRef]

Sparkes, Brian A. 1971. The Trojan Horse in Classical Art. Greece E Rome 18: 54-70.

Starr, Ivan. 1990. Queries to the Sungod: Divination and Politics in Sargonid Assyria. Helsinki: Helsinki University Press.

Strawn, Brent A. 2005. What Is Stronger than a Lion. Fribourg and Göttingen: Universitätsverlag Freiburg Schweiz/Vandenhoeck \& Ruprecht.

Stronach, David. 1978. Pasargadae. Oxford: Clarendon Press.

Stronach, David. 1998. On the Date of the Oxus Gold Scabbard and Other Achaemenid Matters. Bulletin of the Asia Institute 12: 231-48.

Stronach, David. 2009. Riding in Achaemenid Iran: New Perspectives. Eretz-Israel 29: 216-37.

Stronach, David. 2011. A Pipes Player and a Lyre Player: Notes on Three Achaemenid or Near-Achaemenid Silver Rhyta Found in the Vicinity of Erebuni, Armenia. In Strings and Threads: A Celebration of the Work of Anne Draffkorn Kilmer. Edited by Wolfgang Heimpel and Gabriella Frantz-Szabó. Winona Lake: Eisenbrauns, pp. 251-74.

Taqizadeh, Sayyed Hasan. 1938. Old Iranian Calendars. London: Royal Asiatic Society.

Thompson, Georgina. 1965. Iranian Dress in the Achaemenian Period: Problems Concerning the Kandys and Other Garments. Iran 3: 121-6. [CrossRef]

Treister, Mikhail Y. 2015. A Hoard of Silver Rhyta of the Achaemenid Circle from Erebuni. Ancient Civilizations from Scythia to Siberia 21: 23-119. [CrossRef]

Tuplin, Christopher J. 2010. All the King's Horses. In Search of Achaemenid Persian Cavalry. In New Perspectives on Ancient Warfare. Edited by Garrett Fagan and Matthew Trundle. Leiden: Brill, pp. 100-182.

Tuplin, Christopher J. 2014. The Arshama Letters from the Bodleian Library, Volume 3: Commentary. Available online: http:/ /blogs. bodleian.ox.ac.uk/wp-content/uploads/sites/116/2013/10/Volume-3-Commentary-24.12.13.pdf (accessed on 9 May 2014).

Walser, Gerold. 1966. Die Völkerschaften auf den Reliefs von Persepolis. Berlin: Mann.

Watanabe, Chikako E. 1992. A Problem in the Libation Scene of Ashurbanipal. In Cult and Ritual in the Ancient Near East. Edited by His Imperial Highness Prince Takahito Mikasa. Wiesbaden: Harrassowitz, pp. 91-104.

Watanabe, Chikako E. 2000. The Lion Metaphor in the Mesopotamian Royal Context. Topoi Supplement 2: 399-409.

Watanabe, Chikako Esther. 2002. Animal Symbolism in Mesopotamia: A Contextual Approach. Vienna: Institut für Orientalistik der Universität Wien.

Weissbach, Franz Heinrich. 1899. Choaspes (1). Realencyclopädie der Classischen Altertumswissenschaft 3: $2354-55$.

Weissert, Elnathan. 1997. Royal Hunt and Royal Triumph in a Prism Fragment of Ashurbanipal (82-5-22,2). In Assyria 1995. Proceedings of the 10th Anniversary Symposium of the Neo-Assyrian Text Corpus Project. Edited by Simo Parpola and Robert McCray Whiting. Helsinki: Helsinki University Press, pp. 339-58.

Widengren, Geo. 1956. Some Remarks on Riding Costume and Articles of Dress among Iranian Peoples in Antiquity. Arctica: Studia Ethnographica Upsaliensia 11: 228-76.

Wiesehöfer, Josef. 2001. Ancient Persia. Translated by Azizeh Azodi. London: I. B. Tauris.

Wiseman, Donald J. 1952. A New Stela of Aššur-nașir-pal II. Iraq 14: 24-44. [CrossRef]

Zarins, Juris. 1978. The Domesticated Equidae of Third Millennium B.C. Mesopotamia. Journal of Cuneiform Studies 30: 3-17. [CrossRef] 